\title{
KONTROVERZE OKO IZBORA KANDIDATA OTOKA BRAČA ZA DALMATINSKI SABOR U KOTARU VANJSKIH OPĆINA BRAČA, HVARA I VISA 1901. GODINE
}

Jure TRUTANIĆ

Fakultet hrvatskih studija, Odsjek za povijest

Sveučilište u Zagrebu

Zagreb, Hrvatska
UDK: 329(497.5 Brač)“1901“

DOI: $10.21857 /$ ypn4oc1nq9

Prethodno priopćenje

Prihvaćeno: 6. listopada 2020.

Ovaj rad tematizira izbore za Dalmatinski sabor 1901. te političko ozračje u kojem su održani, baveći se prvenstveno kontroverzama proizašlima iz izbora u kotaru vanjskih općina Brača, Hvara i Visa. Na primjeru osporavanog izbora Ante Radića kao kandidata za otok Brač prikazana je sva slojevitost složene političke kombinatorike u lokalnom kontekstu. U mnogim se aspektima rasvjetljava zapostavljena tema o političkim kretanjima na Braču na prijelazu stoljeća, ponajviše kroz djelovanje Petra i Toma Didolića.

Ključne riječi: izbori za Dalmatinski sabor, pravaštvo u Dalmaciji, Brač, Hvar, Ante Radić, Niko Duboković, Tomo Didolić mlađi, Frano Radić.

\section{UVOD}

U prosincu 1901. održani su redoviti pokrajinski izbori za Dalmatinski sabor. Zbog dinamike predizbornih pregovora, neočekivanog ishoda izbora i višemjesečnih polemika koje su uslijedile, posebno zanimljivim pokazao se izbor u kotaru vanjskih općina otoka Brača, Hvara i Visa, osobito po pitanju izbora kandidata za otok Brač. Prelistavanjem dalmatinskog i prekovelebitskog novinstva te pomnim pregledavanjem arhivske građe razasute $u$ pet arhivskih fondova, pred istraživačem se podastire čitav niz suprotstavljenih svjedočanstava o događajima vezanima za određivanje kandidata i konačni izbor saborskog zastupnika za otok Brač. Ta svjedočanstva rašomonski otvaraju niz različitih perspektiva koje doprinose razumijevanju uzroka i sredstava vođenja političke borbe na lokalnim razinama u svoj složenosti zakulisne političke kombinatorike.

Osim doprinosa razumijevanju funkcioniranja kurijalnog izbornog sustava i općenito izbornog procesa u pokrajini Dalmaciji, ovo istraživanje prilog je poznavanju kreiranja politike odozdo, oslikanog u specifičnim lokalnim prilikama, osobito u svjetlu političko-ideološkog raslojavanja na lokalnoj razini otoka Brača. Razvoj pravaštva na Braču koncem 19. stoljeća dosad je neistražena 
tema, kao i brojne druge historiografski značajne teme o sadržajnim kulturnim i političkim zbivanjima na otoku Braču od uvođenja ustavnosti padom Bachova apsolutizma do rasapa Dvojne Monarhije. Iako historiografski neopravdano prešućeno, u lokalnim i pokrajinskim okvirima osobito je značajno kulturno i političko djelovanje selačke posjedničke obitelji Didolić koja je iznjedrila dvojicu narodnih zastupnika u Dalmatinskom saboru. ${ }^{1}$

Izbori za Dalmatinski sabor 1901. u izbornom kotaru vanjskih općina Brača, Hvara i Visa okončani su nepovoljno za Didoliće. Stoga se jedan od njih, Tomo Didolić mlađi, ${ }^{2}$ javlja kao inicijator zapažene, dugotrajne i oštre novinske polemike koja je uslijedila u dalmatinskim stranačkim glasilima. U razračunavanju koje se nerijetko $s$ političke spuštalo na razinu ad hominem, uz Didolića se oglasilo i dobro poznato lice dalmatinskog parlamentarizma druge polovice 19. stoljeća: dugogodišnji saborski zastupnik i načelnik Općine Jelsa, kapetan Niko Duboković Nadalini. ${ }^{3}$

Polemika posebno plijeni pozornost zbog toga što izravno suprotstavlja Didolića i Dubokovića, istaknute članove obitelji koje su odigrale pionirsku ulogu u hrvatskom narodnom preporodu u Dalmaciji, osobito na srednjodalmatinskim otocima. Kapetan Duboković u polemiku se uključio ustajanjem u obranu

1 Zaslužne pripadnike obitelji Didolić poput zastupnika u Dalmatinskom saboru dr. Vicka Didolića (1831. - 1898.) i njegova rođaka, također zastupnika i višegodišnjeg načelnika Općine Selca, Toma Didolića mlađeg (1845. - 1907.), te Vickova brata Petra Didolića (1845. - 1906.) uglavnom se sporadično spominjalo u radovima koji su se bavili temama vezanima za otok Brač ili Selca. Iznenađuje broj faktografskih pogrešaka koje se u pravilu javljaju pri spominjanju obitelji Didolić u takvim radovima. One najčešće proizlaze iz nepoznavanja lokalnih političkih prilika na otoku Braču i/ili iz neupućenosti u obiteljsko rodoslovlje Didolića u kojem se može pronaći više suvremenika $\mathrm{s}$ istim imenom. Primjerice, u radu D. Vrsalovića Povijest otoka Brača, monografiji neosporne znanstvene vrijednosti koja predstavlja polazište za istraživanje povijesne problematike o otoku Braču, autor je u opširnijem poglavlju o preporodnim gibanjima na Braču uslijed nepostojanja istraživanja o Didolićima upao u zamku zbunjujućih rodoslovnih relacija te načinio krupne pogreške zamijenivši Vicka Didolića njegovim rođakom Tomom. Vidi: Dasen Vrsalović, Povijest otoka Brača, Zagreb, 2003., 309.

2 U izvorima se Tomo Didolić pojavljuje i pod imenom Toma, no u radu smo se odlučili za inačicu imena Tomo jer se tako potpisivao sam Didolić. U čakavskom idiomu bračkih Selaca ovo se ime naglašava kao Tômo, a ne Tómo. Stoga genitiv glasi Tôma, a ne Tóme, pa smo se tim pravilom vodili u tekstu. Uz ime Tôma Didolića redovito se piše mlađi, kako bi ga se razlikovalo od njegova rođaka Tôma Didolića starijeg.

3 Vitez Niko Duboković Nadalini (1834. - 1912.) iz slavne brodovlasničke i veleposjedničke obitelji, bio je u više navrata biran za zastupnika u Dalmatinskom saboru kao predstavnik Narodne (hrvatske) stranke, dok je dužnost načelnika Jelse obnašao čak 44 godine (1868. - 1912.). Bio je jedan od osnivača Prve narodne čitaonice u Jelsi i predsjednik Hrvatske stranke. O njegovu djelovanju u Jelsi povodom smrti pisao je jubilarni broj Narodnog lista: Jelsa i kap. Niko Duboković, Narodni list, jubilarni broj, 1. 3. 1912. 
novoizabranog narodnjačkog saborskog zastupnika, bolskog načelnika Ante Radića, ${ }^{4}$ na čijoj se strani naknadno uključio i nesuđeni zastupnik ovoga izbornog kotara dr. Ivan Štambuk. ${ }^{5}$ Nasuprot njima, podržavajući Didolića, Radićev izbor javno su osporavali milnarski načelnik Mate $S_{c a r n e o}{ }^{6}$ te povaljski književnik Mato Ostojić, ${ }^{7}$ obojica pravaši.

Osvrti na izbore u ovom kotaru i dopisi sukobljenih aktera tjednima su bili objavljivani na stranicama najutjecajnijih dalmatinskih političkih glasila Jedinstva, Narodnog lista i Hrvatske krune te na stranicama riječkog Novog lista. U manjoj mjeri vijesti o izborima u ovom kotaru mogu se pratiti na stranicama Il Dalmate i Crvene Hrvatske te u izdanjima zagrebačkih listova Hrvatska i Obzor. $\mathrm{U}$ jeku javne polemike otvorena pisma i priopćenja objedinjena su u zasebnim brošurama u kojima su glavni akteri iznosili svoje verzije događaja, braneći vlastitu ulogu u spornom izboru prebacivanjem odgovornosti i optuživanjem druge strane. Veći dio spora zapravo se odnosio na neostvarenu mogućnost izborne kandidature Frane Radića, ${ }^{8}$ urednika Starohrvatske prosvjete i učitelja u Korčuli, ujedno brata izabranog zastupnika Ante Radića. Iako se u nastaloj polemici osobno nije javno oglasio, stav Frane Radića iščitavamo iz sačuvanog dopisivanja s arheologom fra Lujom Marunom.

4 Antun (Ante) Radić (1855. - 1940.) bio je načelnik Općine Bol na otoku Braču, jedan od osnivača Prve dalmatinske vinarske zadruge u Bolu. U dva navrata bio je zastupnik u Dalmatinskom saboru: 1901. - 1908. i 1908. - 1918., prvo kao predstavnik Narodne hrvatske stranke, a nakon njezine fuzije s pravašima kao predstavnik Hrvatske stranke. Vidi: Katarina PAVEšić, Obiteljska sjećanja, u: Frano Radić: život i djelo, Zbornik radova, ur. Jakov Karmelić i Jadranka Nejašmić, Split, Bol, 2019., $15-19$.

5 Ivan Štambuk (1857. - 1920?), rodom iz Selaca na Braču, bio je dugogodišnji liječnik u Jelsi na Hvaru. Izabran u kuriji veleporeznika splitskog okružja kao narodnjak, bio je zastupnik u Dalmatinskom saboru (1901. - 1908.) Vidi: Kronika kapetana Nike Dubokovića, ur. Pavao Palaversić, Jelsa, 1998., 152.

6 Mate Scarneo bio je pravaški načelnik Milne, iako je obitelj Scarneo u vrijeme borbe za ponarođenje bračkih općina iznjedrila i autonomaškog načelnika Franju Scarnea koji je provodio političko nasilje nad bračkim narodnjacima. Vidi: Josip VRANDEČić, Narodni preporod na otoku Braču, u: Brački zbornik br. 22, Zbornik radova, ur. Ivo Šimunović, Split, 2007., 171, 175.

7 Mato Ostojić (1861. - 1929.) posjednik, književnik i pravaš iz Povalja na Braču, slovio kao vrstan govornik. Vidi: Marijo Ostojić Petrov, Pjesnici braća Ostojić, u: Povaljski zbornik, Zbornik radova, ur. Marijo Ostojić Petrov, Split, 2007., 253 - 274.

$8 \quad$ Frano Radić (1857. - 1933.) bio je učitelj i arheolog, urednik časopisa Starohrvatska prosvjeta. Više o njemu vidi u: Frano Radić: život i djelo, Zbornik radova, ur. Jakov Karmelić i Jadranka Nejašmić, Split - Bol, 2019. 


\section{POLITIČKE PRILIKE U IZBORNOM KOTARU VANJSKIH OPĆINA BRAČA, HVARA I VISA}

Prema Izbornom redu za sabor zemaljski kraljevine Dalmacije izbori za predstavničko tijelo austrijske krunovine Dalmacije provodili su se u četiri kurije, i to: kuriji veleporeznika (deset zastupnika), kuriji trgovačko-obrtničkih komora (tri zastupnika), kuriji gradova (osam zastupnika) te kuriji vanjskih (seoskih) općina (20 zastupnika). Izborni kotar vanjskih općina Brača, Hvara i Visa bio je jedan od 12 izbornih kotareva koji su sačinjavali kuriju vanjskih (seoskih) općina u kojoj se biralo 20 od ukupno 41 dalmatinskog zastupnika (ne računajući dva virilista). Tijekom čitavog razdoblja djelovanja Dalmatinskog sabora u ovom se izbornom kotaru na izborima biralo dvojicu zastupnika. Njihov izbor provodio se posredno - preko biranih birača (izbornika ili elektora), kao što je to bio slučaj u svim kotarevima kurije. Sukladno tomu, birači svake općine prvo su birali određen broj svojih biranih birača koji je za svaku općinu bio određen razmjerno broju stanovnika. U skladu s imovinskim i obrazovnim cenzusom, pravo biranja biranih birača nisu imali svi stanovnici općine. Pravo glasa utvrđivalo se temeljem iznosa izravnog plaćenog poreza, a samo su dvije trećine poreznih obveznika s višim iznosima plaćenog poreza uživale izborno pravo. Iznimke su predstavljali činovnici, svećenici, učitelji, pomorski pisari i kapetani, časnici stalne vojske i osobe s doktoratom koji su pravo glasa stjecali temeljem obrazovanja odnosno stečene profesije, što je bilo u skladu s prevladavajućom doktrinom izbornog prava u europskim državnim sustavima 19. stoljeća. Birani birači sastajali su se nakon zbora u zakazani dan u mjestu određenom za biralište. Tu su među predloženim kandidatima birali svoje saborske zastupnike. Na glasanju bi birač navodio ime osobe kojoj daje glas navodeći onoliko imena koliko se zastupnika biralo u kotaru, a izbori su bili valjani bez obzira na to koliko bi se birača odazvalo na biralište. ${ }^{9}$

U izbornom kotaru vanjskih općina otoka Brača, Hvara i Visa postojalo je nepisano pravilo među biranim biračima da, sukladno zamjetnoj razlici u broju stanovnika na otocima, jedan kandidat bude Bračanin, a drugi Hvaranin ili Višanin. ${ }^{10}$ Po pitanju odabira kandidata uvriježila se također praksa da većina biranih birača slabije napučenih otoka Hvara i Visa glasa za kandidata kojeg bi predložila većina bračkih biranih birača i obratno, ${ }^{11}$ što je važno napomenuti

9 Ivo PERIĆ, Dalmatinski sabor: 1861.-1912. (1918.) god., Zadar, 1978., 17 - 22.

10 Odgovori tiskani u Brojevim 6. i 8. "Jedinstva" godine 1902. na otvoreno pismo upravljeno od gospodina Tome Didolića, mlagjega gospodinu Antunu Radiću načelniku Bola i novoizabranom zastupniku naroda na Dalm. Saboru, Split, 1902., 3 - 4.

11 Budjenje narodne sviesti na Braču, Narodni list, jubilarni broj, 1. 3. 1912. 
jer je nepoštivanje takve prakse jedna od optužbi na koju nailazimo u polemici između Didolića i Dubokovića. Sva ovdje opisana praksa, ona zakonom propisana, kao i ona uvriježena dobrim običajem, ostavljala je pozamašan prostor za raznorazne kombinacije. Te su kombinacije za posljedicu imale žustru političku borbu u kojoj se nerijetko posezalo za svim dozvoljenim, pa i nedozvoljenim sredstvima.

Iščitavajući pregledne tablične prikaze zastupnika poslanih u Dalmatinski sabor iz kotara vanjskih općina Brača, Hvara i Visa nakon 1876. kada autonomaši u njemu trajno gube izglede za osvajanje mandata, stvara se privid o kotaru kao narodnjačkom uporištu koje je redom u saborske sastave slalo narodnjačke zastupnike. ${ }^{12}$ Ipak, konkretna prisutnost pravaštva u Dalmaciji nazire se baš u ovom kotaru uspjehom pravaškog kandidata dr. Roka Mišetića na naknadnim izborima za Dalmatinski sabor 1894. godine. Varljiv dojam uvjerljive narodnjačke prevlasti u kotaru rezultat je kasnog stranačkog organiziranja pravaša u Dalmaciji. Do osnivanja Stranke prava 1894. ponekad se događalo da istaknuti pojedinci bivaju birani u sabor kao zastupnici Narodne stranke, iako su po svom političko-ideološkom habitusu de facto pripadali pravašima. ${ }^{13}$ Kasnije se pak većina dalmatinskih pravaša fuzijom Narodne hrvatske stranke i Stranke prava u Hrvatsku stranku 1905. godine odrekla pravaškog imena, pa su u sabor birani kao zastupnici Hrvatske stranke. ${ }^{14}$

U vremenskom intervalu između te dvije pojavnosti, utemeljenja Stranke prava 1894. i nestanka matice stranke njezinom fuzijom u Hrvatsku stranku, pravaši su u kotaru vanjskih općina Brača, Hvara i Visa egzistirali kao značajan politički faktor. Usred specifičnih okolnosti, nisu uspjeli na redovitim saborskim izborima kapitalizirati svoju političku snagu, čak ni na izborima 1901. na kojima je Stranka prava brojem mandata doživjela svoj najveći uspjeh. Snaga pravaša na lokalnim razinama vlasti manifestirala se ipak na općinskim izborima 1899. Dalmatinski pravaši na tim su izborima nastupili jedinstveno unatoč raskolu, što je rezultiralo osvajanjem vlasti u 24 od 86 dalmatinskih općina. ${ }^{15}$

Iza takve konstelacije snaga i prividno neosporne narodnjačke političke prevlasti u kotaru koja se iz izbora $\mathrm{u}$ izbore iskazivala pobjedom dvaju narodnjačkih kandidata, gotovo u pravilu krila su se otvorena ili zakulisna trvenja, neslaganja i prijepori među otočnim narodnjacima oko odabira kandidata kojeg su na koncu birani birači svojim glasovima slali u sabor.

12 I. PERIĆ, Dalmatinski sabor, 215 - 225.

13 Marjan Diklić, Pravaštvo u Dalmaciji do kraja Prvoga svjetskog rata, Zadar, 1998., 287.

14 I. PERIĆ, Dalmatinski sabor, 215 - 225.

15 M. Diklić, Pravaštvo u Dalmaciji, 314 - 315. 
Prije 1901. godine kao primjer takvog nesuglasja možemo navesti izbore 1889. i nerealiziranu kandidaturu za otok Brač Frane Radića, učitelja u Korčuli, rodom iz Bola na Braču. Ni tjedan dana prije tih izbora nije bio postignut dogovor oko toga iza kojeg će kandidata stati birani birači otoka Brača i ustoličiti ga kao drugog zastupnika ovog kotara uz neprikosnovenog Niku Dubokovića, jelšanskog načelnika i tadašnjeg saborskog zastupnika. Čim je u Narodnom listu bila prenesena vijest o Radiću kao potencijalnom kandidatu te najavljeno objelodanjivanje Radićeva programa, ${ }^{16}$ pravaški nastrojen list Katolička Dalmacija don Ive Prodana oštro je reagirao pišući kako Radić nije Hrvat, već „Srbin od glave do pete.“ Katolička Dalmacija smatrala je da Radićev program neće biti hrvatski, već čisto šumadijski nazivajući ga srbo-bizantincem uz poziv bračkim izbornicima neka biraju Didolića, Mišetića, Deškovića ili Colombisa. ${ }^{17}$ Narodni list zaista je tiskao potom Radićev program uz komentar da je program napisan u hrvatskom duhu i odgovara temeljnom načelu stranke. ${ }^{18}$ Takva ocjena posredno ukazuje na namjeru narodnjačke nomenklature iza Narodnog lista da podrži upravo Radićevu kandidaturu. Na tragu prethodnih istupa Katolička Dalmacija Radićevom je programu prvenstveno zamjerila točku u kojoj Srbe definira kao rođenu braću i sinove jednorodnog i od Hrvata ni po čemu različitog naroda. ${ }^{19}$ Tjedan dana prije izbora i u Katoličkoj Dalmaciji i u Narodnom listu kao možebitni kandidati spominjale su se ugledne javne osobe poput urednika Naroda Dinka Politea, odvjetnika Ante Machieda i liječnika dr. Vale Michielija Tomića. ${ }^{20}$ Naposljetku je, na zadovoljstvo Katoličke Dalmacije, prevagu odnijela nepredvidljiva kandidatura don Stjepana Buzolića za koju su se zauzeli i Didolići. ${ }^{21}$ Buzolić, porijeklom Bračanin iz Milne, jednoglasno je izabran uz hvarskog kandidata Dubokovića, dok je Frano Radić ostao samo kandidatom in spe. Buzolić je nekoliko godina kasnije postao jedan od šestorice narodnjačkih sabornika predvođenih Jurjem Biankinijem koji su, bliski pravaškim načelima, istupili iz matičnog saborskog kluba i formirali zaseban Hrvatski klub. Nije samo Buzolić bio prijemčiv za pravaške programatske odrednice, već su i sva druga imena koja su se spominjala kao možebitni kandidati u kontekstu izbora 1889. na Braču bila naklonjena pravaštvu. Čak je i Frano Radić, Katoličkoj Dalmaciji

16 Brač, 29. svibnja, Narodni list, br. 42, 29. 5. 1889.

17 Pišu nam s Brača, Primamo iz Hvarskog izbornog kotara, Katolička Dalmacija, br. 39, 6. 6. 1889.; Biračima otoka Brača, Katolička Dalmacija, br. 42, 24. 6. 1889.

18 Brač, 12. lipnja, Narodni list, br. 47, 15. 6. 1889.

19 Primamo sliedeće redke, Katolička Dalmacija, br. 41, 17. 6. 1889.

20 Naši dopisi. Starigrad na Hvaru II., Katolička Dalmacija, br. 40, 13. 6. 1889.; Brač, 24. lipnja, Narodni list, br. 50, 26. 6. 1889.

21 Ivan Kazimir Ostojıć, Tomo Didolić i njegovo dopisivanje, Split, 1929., 124 - 127. 
neprihvatljiv kandidat zbog ideološkog koncepta narodnog jedinstva, kasnije politički stasao u starčevićanca. To je vidljivo iz pisma korčulanskih radnika Anti Starčeviću 1894. godine. ${ }^{22}$ Može se stoga zaključiti da su Prodanove poruke krajem 1880-ih nalazile svoju publiku u Dalmaciji, a pravaštvo na Braču, promicano i iz drugih krugova, bilo je snažno prisutno na otoku još prije formalnog utemeljenja Stranke prava 1894. godine.

Prva konkretnija manifestacija pravaštva u Dalmaciji sadržana je u političkom skupu hrvatske mladeži s Brača, Hvara i Makarskog primorja održanom u Selcima na otoku Braču 27. i 28. kolovoza 1883. godine. ${ }^{23}$ Jedan od glavnih organizatora bio je Tomo Didolić ml., posjednik iz porodice koja je kulturno-političkom životu na istoku Brača nedvojbeno određivala dinamiku i dominantno usmjerenje. Uz Toma i njegova rođaka Petra Didolića, na Braču je na prijelazu stoljeća djelovalo još nekoliko istaknutih pravaša poput don Ante Milićevića iz Nerežišća, don Petra Zlatara, župnika u Donjem Humcu, i milnarskog načelnika Mate Scarnea. ${ }^{24}$ Kroz sačuvane dokumente vezane uz rad Stranke prava u Dalmaciji kao istaknuti brački pravaši figuriraju i drugi pojedinci. U popisu uzvanika na sastanak Hrvatskog političkog društva koje je u praksi djelovalo kao tijelo Stranke prava, održan u Splitu 20. 10. 1900., navedena je većina njih: Petar Baturić, liječnik u Pučišćima, zatim pučiški načelnik Ivo Marija Maroević, Niko Petrić mlađi iz Bola, povaljski književnik Mato Ostojić, supetarski odvjetnik Vicko Nisiteo, Vicko i Aleksandar Karlovac iz Supetra te prisjednik Lukšić iz Sutivana. ${ }^{25}$

Već spomenuti naknadni izbor pravaškog kandidata dr. Roka Mišetića na mjesto preminulog člana Hrvatskog kluba don Stjepana Buzolića 1894. potvrdio je zamah pravaštva na Braču i konkretniji parlamentarni iskorak. No sve je ostalo na tom nagovještaju s obzirom na to da pravaši u sljedeća dva izborna ciklusa prije fuzije matice Stranke prava u Hrvatsku stranku u ovom kotaru nisu uspjeli izboriti mandat. ${ }^{26}$

22 Nacionalna i sveučilišna knjižnica, Zagreb (NSK), Zbirka rietkosti, ostavština Frane Radića, R 6300 C, Pismo F. Radića u ime korčulanskih radnika A. Starčeviću, 1894.

23 O tome u: Ivo Perić, Politički skup hrvatske mladeži u Selcima (1883.) u svjetlu početnog širenja pravaštva na dalmatinskom prostoru, Radovi Zavoda za povijesne znanosti HAZU u Zadru, sv. 37, Zadar, 1995., 717 - 728.

24 Sveučilišna knjižnica u Splitu, Arhiv dr. Ante Trumbića (dalje: SVKST, Arhiv Trumbić + M), M 483/7, Vrli pravaši.

25 SVKST, Arhiv Trumbić, M 483/10, Poziv na sastanak HPD.

26 Dr. Roko Mišetić bio je ravnatelj dubrovačke bolnice, koji je jedno vrijeme bio i osobni liječnik crnogorskog kneza Nikole Petrovića. Kao Bračanin rodom iz Splitske, već je 1886. kao narodnjak bio izabran za saborskog zastupnika na naknadno raspisanim izborima u kotaru vanjskih općina Brača, Hvara i Visa. O njemu u: † Roko vitez Mišetić, Hrvatska kruna, 4. 2. 1908. 
Ni Mišetićev izbor nije bio lišen prijepora. Neki narodnjaci na čelu sa supetarskim načelnikom Dinkom Rendićem tijekom narodnjačko-pravaških prepucavanja u kontekstu saborskih izbora 1895. post festum su nijekali da su godinu ranije na naknadnim izborima podržali Mišetića kao osvjedočenog pravaša. Tvrdili su kako su za Mišetića glasali ne znajući za njegov pravaški program i namjeru da nakon izbora stupi u Biankinijev pravaški klub u saboru. ${ }^{27}$ Njihove tvrdnje osporava pismo otposlano uoči naknadnih izbora 1894. u kojem Petar Didolić izvještava Antu Trumbića kako je na supetarskoj skupštini jedan od dogovorenih uvjeta za izbor kandidata bio taj da izabrani bude pravaš koji će stupiti u Klub stranke prava. Upravo na Didolićev prijedlog, kao kandidat, bilo za naknadni, bilo za redoviti izbor, prihvaćen je velikom većinom dr. Roko Mišetić. Protiv su bila samo tri Sutivanjana te dr. Tomić i glavar Škripa koji su ranije napustili sastanak, dok predstavnici Bola nisu ni sudjelovali na toj skupštini bračkih predstavnika općina. ${ }^{28}$

Na redovitim izborima u kotaru vanjskih općina Brača, Hvara i Visa 1895. godine izabrani su s po 61 glasom narodnjački kandidati odvjetnik Ante Colombis s Brača ${ }^{29}$ i posjednik Ante Petrić, načelnik Visa, nasuprot pravaškim kandidatima, liječnicima Roku Mišetiću i Niki Marinkoviću, koji su sakupili samo po 20 glasova. ${ }^{30}$ Dvojica narodnjačkih kandidata, sudeći po novinskim napisima, odabrana su pod stanovitim utjecajem političkog inženjeringa narodnjačkog kruga u Splitu okupljenog oko Gaje Bulata, politički nesklonog suradnji s pravašima. ${ }^{31} \mathrm{Ti}$ saborski izbori 1895. u kotaru vanjskih općina Brača, Hvara i Visa također imaju svoje manje reprezentativno naličje. Nakon izbora biranih birača po kotarevima vanjskih općina, Biankinijev Narodni list optuživao je narodnjake, Srbe i autonomaše za izbornu urotu protiv pravaša uz blagoslov i podršku organa državne vlasti. Prozivalo se političke suparnike, izborna povjerenstva i žandare za političko nasilje, izborne makinacije i nepravilnosti, a izbore opisivalo kao izbornu komediju. ${ }^{32}$ Nakon izbora došlo je do žustrih polemika pravaša predvođenih liječnikom dr. Nikom

27 Iz obćine supetarske, Narodni list, br. 66, 17. 8. 1895.; Vis, 11 rujna, Narodni list, br. 74, 14. 9. 1895.

28 SVKST, Arhiv Trumbić, M 425/10, Pismo P. Didolića A. Trumbiću od 18. 9. 1894.

29 Ante Colombis iz Supetra na Braču bio je jedan od onih narodnjaka bliskih pravaštvu koji se našao među pozvanima na osnivačku konferenciju Stranke prava održanu 22. i 23. kolovoza 1894. godine u Zadru, no ipak je ostao lojalan Narodnoj stranci. Vidi: M. Di klıć, Pravaštvo u Dalmaciji, 263.

30 Brzopisna izvješća XXXI zasjedanja pokrajinskoga sabora dalmatinskoga od dneva 25. siječnja do dneva 10. veljače 1896., Zadar, 1896.

31 Iz obćine supetarske, Narodni list, br. 66, 17. 8. 1895.

32 Poslie izbora biranih birača, Narodni list, br. 71, 4. 9. 1895.; Izbori vanjskih općina i gradova, Narodni list, br. 73, 11.9. 1895. 
Marinkovićem $s$ viškim i hvarskim narodnjacima na stranicama splitskog Jedinstva i zadarskog Narodnog lista. ${ }^{33}$

Godine 1895. u prvom izlasku na redovite izbore po osnivanju stranke, sva tri na pokrajinskoj razini osvojena mandata (Josip Virgil Perić, Juraj Biankini i Ante Trumbić) pravaši su izborili u kuriji vanjskih (seoskih) općina, nekadašnjem uporištu narodnjaka. ${ }^{34}$ Stoga je bilo jasno kako će upravo ta kurija imati ključan značaj za pravaše u narednim redovitim pokrajinskim izborima, onima 1901. godine.

\section{POLITIČKI KONTEKST IZBORA ZA DALMATINSKI SABOR 1901. GODINE}

Unatoč oštroj izbornoj borbi za zastupnička mjesta 1895. popraćenoj međusobnim optuživanjima pravaša i narodnjaka, usporedno $s$ višegodišnjim procesom postupnog okupljanja oporbenih snaga u Banskoj Hrvatskoj, taj je proces, uz brojne specifičnosti, uzeo maha i u Dalmaciji. Na tom je tragu politički pragmatizam iznjedrio narodnjačko-pravaške izborne suradnje. Prvo su Stranka prava i Narodna hrvatska stranka sklopile izborni sporazum o zajedničkom izlasku na izbore za Carevinsko vijeće 1897. godine temeljem kojeg su pravaši dobili tri zastupnička mjesta. Sličan aranžman ponovljen je koncem 1900. prigodom prijevremenih izbora za Carevinsko vijeće usprkos disonantnim mišljenjima unutar Stranke prava. Narodnjačko-pravaška suradnja uspostavljena je i prilikom naknadnog izbora četvorice zastupnika u Dalmatinskom saboru u ožujku 1901. godine na kojima su pravaši u dogovoru s narodnjacima osvojili dva od četiri zastupnička mjesta. ${ }^{35}$

Zbližavanje dviju stranaka postalo je izvjesnije nakon nestanka s političke pozornice korifeja narodnjačke oportunističke politike, prvo Mihe Klaića (umro 1896.), a zatim Gaje F. Bulata i Ivana Vrankovića (umrli 1900.) koji suradnji s pravašima nisu bili nakloni. Odcjepljenjem od matice dalmatinske Stranke prava, izbornoj suradnji s narodnjacima protivne, Prodanove skupine $1898 .{ }^{36}$ osnažio

33 Otvoreno pismo biranim biračim obćine Jelšanske, Narodni list, br. 73, 11. 9. 1895.; Vis, 13. rujna, Narodni list, br. 75, 18. 9. 1895.; Prilog broju 76, Narodni list, br. 76, 21. 9. 1895.; Vis, 20. rujna, Narodni list, br. 77, 25. 9. 1895.; Vis, 27. rujna, Narodni list, br. 80, 5. 10. 1895.; Vis 3. listopada, Narodni list, br. 81, 9. 10. 1895.; Sa otoka Hvara, Narodni list, br. 82, 12. 10. 1895.; Vis 14. listopada, Narodni list, br. 85, 23. 10. 1895.; Jelsa, 24. listopada, Narodni list, br. 87, 30. 10. 1895.

34 I. PERIĆ, Dalmatinski sabor, 222 - 223.

35 M. Diklić, Pravaštvo u Dalmaciji, 291 - 292, 320 - 323.

36 M. Diklıć, Pravaštvo u Dalmaciji, 306. 
je potencijal za izbornu suradnju Stranke prava. Secesijom prodanovaca vrata suradnji matice dalmatinske Stranke prava s Čingrijinom Narodnom hrvatskom strankom našla su se širom otvorena, dok je istovremeno trojac Trumbić - Supilo - Biankini sa suradnicima mogao i dalje računati na suradnju s politički srodnom Prodanovom Čistom strankom prava što će se pokazati nakon izbora 1901. Tada su izabrani pravaški zastupnici obiju frakcija formirali zajednički saborski klub, iako prethodno nisu uspjeli dogovoriti sporazumni izlazak na izbore. ${ }^{37}$

Unatoč političkom približavanju narodnjaka i pravaša, uslijed sve izraženije ideološko-političke diferencijacije u hrvatskim redovima uslijedila je stranačka fragmentacija i usložnjavanje odnosa na dalmatinskoj političkoj pozornici. Kao posljedica tog procesa, na izborima za Dalmatinski sabor 1901. godine, prvi put od utemeljenja tog predstavničkog tijela, na pokrajinskoj razini dolazi do izbornog natjecanja između čak tri hrvatske stranke: Narodne hrvatske stranke, Stranke prave i Čiste stranke prava. Prirodno se stoga postavljalo pitanje kako će se hrvatske opcije ponašati na predstojećim izborima za Dalmatinski sabor 1901.

Uoči devetih izbora za Dalmatinski sabor održanih koncem 1901. došlo je do određenih nastojanja da se prevlada rascjep između dvije frakcije pravaša kako bi zajednički nastupili na izborima. No taj pokušaj nije urodio plodom. Dalmatinska Čista stranka prava odlučila je sama izaći na izbore, nakon čega su između Biankinijevih pravaša i narodnjaka uslijedili pregovori o izbornoj suradnji. ${ }^{38}$

Carskom poveljom od 1. listopada 1901. raspušten je pokrajinski sabor i zakazani su izbori na sljedeće datume: u kuriji vanjskih općina za 10. prosinca, u kuriji trgovačkih i obrtničkih komora te kuriji gradova za 12. prosinca te $\mathrm{u}$ kuriji veleporeznika na 21. prosinca. ${ }^{39}$ Mjesec listopad 1901. u Dalmaciji su u političkom smislu obilježila dva važna događaja. Prvi je bila proslava održana 13. listopada povodom 30. godišnjice Biankinijeva uređivanja Narodnog lista. Sastojala se od sobeta priređenog u foyeru splitskog kazališta te komersa održanog u kavani na Novoj obali. ${ }^{40}$ Drugi značajan događaj bio je sastanak svih hrvatskih načelnika pokrajine održan uz zajednički objed u hotelu Pirola na poziv splitskog načelnika Vinka Milića 16. listopada $1901 .{ }^{41} \mathrm{Na}$ sastanku su

37 M. Diklić, Pravaštvo u Dalmaciji, 324, 326 - 327.

38 M. Diklić, Pravaštvo u Dalmaciji, 324.

39 Izbori razpisani, Narodni list, br. 84, 19. 10. 1901.

40 SVKST, Arhiv Trumbić, M 447/IV.1, Pismo odbora za proslavu od 26. 9. 1901.

41 Sastanak, Jedinstvo, br. 84, 18. 10. 1901.; Sastanak hrvatskih načelnika u Spljetu, Novi list, br. 240, 21. 10. 1901 . 
načelnici i predstavnici dalmatinskih općina jednoglasno usvojili zaključak da se svi dalmatinski Hrvati slože u zajednički rad na obranu narodnih prava i da svi Hrvati kod predstojećih izbora budu složni, misleći prvenstveno na slogu između Narodne hrvatske stranke i matice dalmatinske Stranke prava. ${ }^{42}$ Nakon tog sastanka ipak je postajalo sve jasnije da će do sloge teško doći. Iz Biankinijevih pisama Trumbiću iščitava se kako je narodnjak dr. Vicko Ivčević nepopustljiv u pregovorima, pa je Biankini naslućivao kako od sporazuma neće biti ništa. ${ }^{43}$

Nešto više od mjesec dana poslije sastanka dalmatinskih načelnika, 22. studenog 1901., održan je zbor zastupnika i načelnika Narodne hrvatske stranke. Njegovim odlukama dokinut je val entuzijazma o složnom izlasku narodnjaka i pravaša na izbore. ${ }^{44}$ Dan nakon sastanka u narodnjačkom glasilu Jedinstvo izašla je štura vijest kako je na zboru Hrvatske narodne stranke odlučeno da se Stranci prava prepusti 7 mandata ${ }^{45}$ Sudeći po pojedinim novinskim napisima, na narodnjačkom sastanku pravašima je prvotno bilo ostavljeno samo 6 mandata, na što je Lovro Borčić predložio 8, za što su glasali on, dr. Pero Čingrija i bolski načelnik Ante Radić. Na koncu je prihvaćen kompromisni prijedlog da se pravašima ponudi 7 mandata, ${ }^{46}$ čime je prevladala Morpurgova struja. ${ }^{47}$ Prema Dubokoviću, Trumbić je u jednom pismu pisao Biankiniju da bi trebalo tražiti 12 mandata, ${ }^{48}$ pa u tom smislu ne čudi što je potom kao odgovor na odluke zbora na naslovnici Narodnog lista osvanuo oglas Hrvatskog političkog društva o prekidu pregovora s narodnjacima i samostalnom izlasku Stranke prava na predstojeće izbore. U oglasu se naglašava kako se na temelju jednoglasnog zaključka načelničkog sastanka u Splitu 16. listopada 1901. držalo da je sporazum gotova stvar, no Narodna stranka na koncu je ponudila pravašima samo 7 mandata da bi osigurala natpolovičnu većinu u novom sazivu sabora, što je pravašima neprihvatljivo. Oglasom se pozivaju birači neka glasaju za predloženike Stranke prava koji će naknadno biti proglašeni. Među potpisnicima koji stoje iza oglasa nalazi se i brački pravaš, član Odbora Hrvatskog političkog društva Petar Didolić. ${ }^{49}$

42 U foyeru općinskoga kazališta, Jedinstvo, br. 98, 6. 12. 1901.

43 SVKST, Arhiv Trumbić, M 452/8, Pismo J. Biankinija A. Trumbiću od 9. 11. 1901.

44 Zbor narodne hrvatske stranke, Jedinstvo, br. 94, 22. 11. 1901.

45 Izborna hronika, Jedinstvo, br. 95, 26. 11. 1901.

46 Izbori u Dalmaciji, Novi list, br. 275, 2. 12. 1901.

47 Spljet, 25. Novembra, Crvena Hrvatska, br. 48, 30. 11. 1901.

48 Častnom gospodinu Tomi Didoliću pok. Vicka, Jedinstvo, 7. 3. 1902., novinski isječak dostupan u: Hrvatska - Državni arhiv u Splitu, Split (dalje: HR-DAST), fond 617, Obiteljski fond Duboković Nadalini (dalje: f. Duboković), kut. 10, fasc. XXVIIII.

49 Hrvati!, Narodni list, br. 95, 27. 11. 1901. 
Unatoč sadržaju objavljenog oglasa, pregovori između narodnjaka i pravaša ipak su nastavljeni jer su narodnjaci usprkos odlukama svog sastanka bili neodlučni kao da se pribojavaju pogrešnog koraka. ${ }^{50}$ Pregovori koji su uslijedili ponegdje su urodili plodom. Mjesni odbori u Splitu i Sinju uglavili su sporazum da se u kotarevima vanjskih općina Splita, Trogira i Omiša te kotaru vanjskih općina Sinja izabere jedan predloženik narodnjak, a drugi pravaš. Narodni list objasnio je potom kako Stranka prava unatoč sporazumu u nekim kotarevima načelno ostaje pri samostalnoj akciji, kao što je to bilo i naglašeno u izbornom proglasu, ali ostavlja otvorenu mogućnost svojim pristašama da odluče hoće li na izborima nastupati samostalno ili će se sporazumjeti s narodnjacima. Proglas također upućuje birače neka tamo gdje Stranka prava ne istakne svoje kandidate glasaju za Hrvate. ${ }^{51}$ Time je Stranka prava ostavila de facto otvorena vrata suradnji tamo gdje se ukaže prilika, usprkos prije objavljenom pompoznom proglasu Odbora Hrvatskog političkog društva o samostalnom izlasku na izbore.

Naposljetku se žestoka izborna borba vodila u Šibeniku i Makarskoj u kuriji gradova. U Šibeniku su pravaši preko čistog pravaša - kanonika Tambače ujedinjeno, ali neuspješno nastupili s ciljem rušenja viteza Ante Šupuka. Više su uspjeha imali u Makarskoj gdje je svećenik Nikola Ribičić uspio glasovima nadjačati umirovljenog dvorskog savjetnika - viteza Antuna Vukovića. ${ }^{52}$ Nakon što su odrađeni izbori u kuriji vanjskih općina, veliku je buru u novinama podigao izbor trgovca Josipa Bakote s Raba. Bakota se deklarirao kao Biankinijev čovjek, da bi na dan izbora na biralištu osvanuo kao kandidat čistih. Izborom Bakote i don Ive Prodana Čista stranka prava osvojila je oba mandata u kotaru vanjskih općina Zadra, Paga i Raba, iako se do zadnjeg časa radilo na sporazumu između dvije pravaške stranke kako bi Biankinijevi pravaši i Prodanovi čisti dobili po jedan mandat..$^{53}$

Nakon što se slegla prašina oko izbora Bakote, u prvi su plan novinstva izbile napetosti oko izbora u kotaru vanjskih općina Brača, Hvara i Visa. Odmah nakon izbora spomenuo ih je čak i zagrebački Obzor koji nije sustavnije izvještavao o izborima u Dalmaciji. ${ }^{54} \mathrm{U}$ ovom su kotaru 10. prosinca 1901. izabrana dvojica narodnjaka, iako je po omjeru snaga logičan scenarij bio onaj dogovorne podjele mandata između narodnjaka i pravaša koji su činili značajan politički faktor u

so SVKST, Arhiv Trumbić, M 452/10, Pismo J. Biankinija A. Trumbiću od 28. 11. 1901.

51 Izborno sgodopisje, Narodni list, br. 97, 4. 12. 1901.

52 Izbori u Dalmaciji, Novi list, br. 285, 13. 12. 1901.

53 Izborno sgodopisje, Narodni list, br. 99, 11. 12. 1901.; Dvie rieči odgovora, Narodni list, br. $100,14$. 12. 1901.

54 Izbori u Dalmaciji, Obzor, br. 286, 12. 12. 1901. 
kotaru. Od 84 birana birača registrirana u kotaru vanjskih općina Brača, Hvara i Visa izborima u gradu Hvaru 10. prosinca 1901. pristupio je 81 birač. Izabrani su većinom glasova prisutnih pomorski pisac i pedagog - upravitelj nautičke škole u Kotoru - Juraj Carić te načelnik Bola Ante Radić, obojica s po 47 glasova. U manjini su ostali donačelnik Općine Selca Tomo Didolić ml. te komiški župnik don Ivo Bojanić s po 34 glasa. ${ }^{55}$ Birani birači po mjestima su glasali ovako: za narodnjačke kandidate Bol 4/4, Pučišća 5/7, Postira 4/4, Nerežišća 4/4, Supetar $3 / 6$, Sutivan 3/4, Komiža 8/8, Vis 9/9, Jelsa 7/7, a za kandidate ujedinjenih pravaša Selca 6/6, Pučišća 1/7, Supetar 2/6, Sutivan 1/4, Milna 9/9, Hvar 3/3, Stari Grad $3 / 3$, Vrboska $7 / 7$, Bogomolje $2 / 2$. Jedan se pučiški birani birač nije prihvatio glasanja, jedan je supetarski birač bio bolestan, kao i jedini birač iz Sućurja koji također nije birao. ${ }^{56} \mathrm{Na}$ koncu je izbor Jurja Carića bio posve očekivan, s obzirom na to da taj narodnjački mandat, kao ni Carićev ugled i zasluge, nitko načelno nije ni osporavao. Neočekivanom se ne može nazvati ni kandidatura don Ive Bojanića koja je bila prije izbora javno oglašena. Čista stranka prava bila je u ovom kotaru, kao i u ostatku Dalmacije, najavila samostalan izlazak na izbore te kao svoje kandidate tjedan dana prije izbora oglasila dr. Petra Baturića i don Ivu Bojanića. ${ }^{57}$ Ono što je izazvalo brojne prijepore jest neočekivana, no uspješno istaknuta kandidatura bolskog načelnika Ante Radića. Koliko je njegov izbor bio neočekivan potvrđuje vijest o rezultatima izbora u Dalmaciji objavljena u zagrebačkom listu Hrvatska u kojoj piše da je navod o izboru gospodina Radića, načelnika Bola, vjerojatno pogreška jer se nije on kandidirao, već njegov brat učitelj. ${ }^{58}$ Iznenađujuć je bio i pokušaj ulaska u sastav sabora Toma Didolića mlađeg, bivšeg sabornika koji se još davno bio povukao iz aktivne politike na pokrajinskoj razini odricanjem od saborskog mandata 1886. godine, ${ }^{59}$ a zatim se prestankom obnašanja dužnosti općinskog načelnika 1892. poprilično pasivizirao i na lokalnoj razini politike uslijed secesije u Hrvatskoj narodnoj stranci. ${ }^{60} \mathrm{Na}$ tom tragu ne treba smetnuti s uma kako je ovaj kotar bio jedan od onih na koje se 7. prosinca u Narodnom listu aludiralo viješću da se birači nisu sporazumjeli

55 Brzopisna izvješća XXXVII zasjedanja pokrajinskoga sabora dalmatinskoga od dneva 24 juna do dneva 26 jula 1902, Zadar, 1902., 281.

56 HR-DAST, f. 617, Duboković, kut. 10, fasc. XXVIII, Izbori za sabor 1901. Glasovi biranih birača po mjestima.

57 Izborno sgodopisje, Narodni list, br. 97, 4. 12. 1901.

58 Izbori u Dalmaciji, Hrvatska, br. 286, 12. 12. 1901.

59 Javne zahvale, Narodni list, br. 59, 31. 7. 1886. Ivo Perić pogrešno navodi 1885. kao godinu Didolićeva povlačenja iz sabora. Vidi: I. PERIć, Dalmatinski sabor, 221.

60 Priobćeno, Narodni list, br. 14, 15. 2. 1902. 
pa se još ne mogu oglasiti imena kandidata. ${ }^{61}$ Nakon okončanja izbora biranih birača početkom prosinca, pretpostavljalo se da će jezičac na vagi u ovom kotaru predstavljati sedmorica pučiških biranih birača ${ }^{62}$ te četvorica biranih birača iz Bola koji su slovili kao narodnjaci. No, Narodni list objavio je šest dana prije izbora vijest da su bolski birači ipak spremni glasati i za pravaša ako bi to bio načelnikov brat, učitelj Frano Radić. ${ }^{63} \mathrm{U}$ kuloarima se izvan stranica stranačkih glasila tik pred izbore vrlo konkretno spominjalo ime dr. Ivana Štambuka, liječnika u Jelsi, kao potencijalnog kandidata Narodne hrvatske stranke u kotaru vanjskih općina Brača, Hvara i Visa, ali ime Ivana Štambuka javno je osvanulo 21. prosinca u novinskim izbornim vijestima među imenima trojice izabranih zastupnika u kuriji veleporeznika splitskog okružja. ${ }^{64}$ Ovakav je rasplet događaja bio uvod u višemjesečni rat otvorenim pismima, brošurama i dopisima koji se sa zanimanjem pratio u javnosti, a odrazio se i na bračke političke prilike, osobito u Selcima, rodnom mjestu nesuđenog zastupnika Didolića i novoizabranog zastupnika Štambuka.

\section{KONTROVERZE OKO IZBORA U KOTARU VANJSKIH OPĆINA BRAČA, HVARA I VISA}

Dok su zagrebački listovi u vrijeme dalmatinskih izbora bili zaokupljeni prvenstveno minulim izborima za Hrvatski sabor i pripremama oko dugo iščekivanog ujedinjenja hrvatskih oporbenih snaga, zapaženu novinsku refleksiju na netom završene izbore za Dalmatinski sabor iznio je riječki Novi list. Ugledni novinar Dinko Politeo u Novom listu, u seriji od tri članka, opširnije se osvrnuo baš na izbor u kotaru vanjskih općina Brača, Hvara i Visa. ${ }^{65}$ Iako je dugo vremena boravio u Zagrebu, udaljen od zavičaja rodnog mu Starog Grada na Hvaru, Politeo je, pogođen bolešću i potpuno slijep, zadnjih godina života i dalje prepoznatljivim stilom i smislom za političku analizu objavljivao uvažavane članke o političkim prilikama u Dalmaciji. ${ }^{66}$ Između ostalih, o dalmatinskim političkim prilikama informirao ga je i prijatelj s Brača Tomo Didolić ml. ${ }^{67} \mathrm{U}$

\footnotetext{
61 Izborno sgodopisje, Narodni list, br. 98, 7. 12. 1901.

62 HR-DAST, f. 617, Duboković, kut. 10, fasc. XXVIII, Brzojavi N. Dubokoviću od 8. i 9. 12.1901.

63 Izborno sgodopisje, Bol, Narodni list, br. 97, 4. 12. 1901.

64 Izborno sgodopisje, Split, Narodni list, br. 102, 21. 12. 1901.

65 Poslie izbora u Dalmaciji, Novi list, br. 295, 27. 12. 1901.; Odjeci dalmatinskih izbora, Novi list, br. 28, 4. 2. 1902.; Još odjeci dalmatinskih izbora, Novi list, br. 40, 18. 2. 1902.

66 Cvjetko ŠKARPA, Dinko Politeo: studija, Zagreb, 1933., 13 - 16.

67 I. K. Ostojić, Tomo Didolić, 133 - 148.
} 
osvrtima na minule saborske izbore u Dalmaciji Politeo njihov ishod doživljava kao evoluciju u stranačkim odnosima. Pozivanjem na narod zastupnike upućuje na oživotvorenje modernog narodnog načela na osnovi povijesnog i državnog prava. Iz rezultata izbora Politeo zaključuje da je narod sve zastupnike koji vjeruju u hrvatsku budućnost uputio na Biankinija te smatra kako upravo on mora postati središte stranačkog okupljanja. Kao pobornik sloge hrvatskih stranaka općenito je zadovoljan zbližavanjem dalmatinskih narodnjaka i pravaša, no iskazuje žaljenje nad podjelama, prvenstveno u novinama koje stvaraju jaz među biranim zastupnicima dijeleći ih pojednostavljeno na narodnjake i pravaše. Politeo ističe kako zastupnici nisu birani ni kao narodnjaci ni kao pravaši, već kao hrvatski rodoljubi. ${ }^{68}$ Zaista se pripadnost stranci nije tada dokazivala članskom iskaznicom, već sasvim proizvoljnim načinima. Tako dr. Ivan Štambuk prilikom jednog istupa u Narodnom listu 1902. svoju pripadnost Narodnoj hrvatskoj stranci proteklih godina dokazuje činjenicom da je primao njezino stranačko glasilo. ${ }^{69}$

Borbu između narodnjaka i pravaša u Šibeniku i Makarskoj Politeo smatra opravdanom, ali piše kako treba žaliti borbu do koje je došlo u kotaru vanjskih općina Brača, Hvara i Visa. Što se tiče tog kotara, smatra kako nitko ne prigovara i nema osnove prigovoriti izboru Jurja Carića, no može i mora prigovoriti izboru Ante Radića. Politeo uspoređuje izbor Radića s kontroverznim izborom trgovca Josipa Bakote u Zadru jer su se kandidature u oba slučaja promijenile doslovno preko noći. Politeo je mišljenja da je na obojicu spomenutih djelovala napast zastupničkog mandata, iako za obnašanje te časti nemaju nužnih uvjeta. Ističe kako su Radić i Bakota jedina dvojica zastupnika izabrana na ovim izborima koje nisu u zastupničku stolicu dovele njihove sposobnosti i zasluge. ${ }^{70}$ No čula su se po tom pitanju i mišljenja oprečna Politeovima. Dr. Ivan Štambuk, izabran u kuriji splitskih veleporeznika, smatra da je Ante Radić zbog ekonomske situacije u pokrajini prikladniji i sposobniji zastupnik od njega i od Toma Didolića, ${ }^{71}$ aludirajući pri tome najvjerojatnije na Radićev zapažen angažman u osnivanju Prve dalmatinske vinarske zadruge $u$ Bolu. ${ }^{72}$ Politeo nadalje zamjera Radiću što je na dan izbora gurnuo sebe u prvi plan, dok se u predvečerje izbora zalagao za izbor svog brata koji nikome ne bi smetao. Spominje Politeo prisilna pisma koja

68 Poslie izbora u Dalmaciji, Novi list, br. 295, 27. 12. 1901.

69 Velecijenjeni gosp. uredniče!, Jedinstvo, 11. 3. 1902., novinski isječak dostupan u: HR-DAST, f. 617, Duboković, kut. 10, fasc. XXVIII.

70 Poslie izbora u Dalmaciji, Novi list, br. 295, 27. 12. 1901.

71 Velecijenjeni gosp. uredniče!, Jedinstvo, 11. 3. 1902., novinski isječak dostupan u: HR-DAST, f. 617, Duboković, kut. 10, fasc. XXVIII.

72 O osnovanju vinarske zadruge A. Radić pok. Gjura svojim sumješćanima u Bolu godine 1899., Split, 1899. 
su brački birani birači navodno dobivali iz Splita u čijem ih se sadržaju uvjeravalo da moraju glasati za dva narodnjaka i odbiti narodnjačko-pravaški kompromis. Postavlja pitanje zašto narodnjaci, kad su već tako odlučili, nisu birali nekog zaslužnog narodnjaka iz preporodnih borbi kao što je supetarski odvjetnik (i načelnik) Ante Colombis, nego su se odlučili za Antu Radića. ${ }^{73}$ Pri takvom razmišljanju Politeo ne uzima u obzir činjenicu da je tijesna većina ovisila upravo o bolskim biračima. Posebno žali što su izbori doveli do raskola između Dubokovića i Didolića, zaslužnih rodoljuba iz preporodnog vremena ponarođivanja općina na srednjodalmatinskim otocima. ${ }^{74}$ Poznavajući njihove zasluge, Politeo ispravno naglašava pogubnost tog raskola. On zaista jest simptom promijenjenih političkih okolnosti u Dalmaciji koji paradigmatski oslikava postupnu političko-ideološku diferencijaciju i razmimoilaženje unutar struktura dalmatinske kulturno-političke elite stasale u krilu stare Narodne stranke.

Ulogu koju su u preporodnom razdoblju na istočnom dijelu otoka Brača odigrali Didolići zajedno s pojedincima iz porodica Nisiteo, Štambuk, Vrsalović, Ostojić, Novaković, Mateljan i drugih, ${ }^{75}$ na otoku Hvaru predvodio je kapetan Niko Duboković Nadalini; Bio je načelnik Jelse 44 godine, a Jelsa je pod njegovim načelnikovanjem postala rasadnik širenja hrvatske misli u druga hvarska naselja. ${ }^{76}$

Duboković je kao kandidat Narodne stranke upravo u izbornom kotaru vanjskih općina Brača, Hvara i Visa izborio tri mandata zaredom za zastupnika u Dalmatinskom saboru (1876. - 1883., 1883. - 1889., 1889. - 1895.). U istom izborništvu na pokrajinskim izborima 1883. narodnjački sukandidat Dubokoviću bio je Tomo Didolić $\mathrm{ml} .{ }^{77}$ Didolić je tada izborio mandat, ali ga, za razliku od Dubokovića, nije konzumirao do kraja saborskog saziva. ${ }^{78}$ Reminiscencije na to razdoblje oslikava i sam Tomo Didolić u jednom od svojih poslijeizbornih priopćenja pišući Dubokoviću kako će ga i dalje štovati s obzirom na ono vrijeme kada su zajedno stajali rame uz rame u narodnim borbama. Iako je Didolićbio mlađi i manji od Dubokovića, Duboković i njegovi častili su ga svojim prijateljstvom. ${ }^{79}$ Nakon kontroverznih izbora Didolić i Duboković čestitali su si Novu godinu, no

73 Poslie izbora u Dalmaciji, Novi list, br. 295, 27. 12. 1901.

74 Poslie izbora u Dalmaciji, Novi list, br. 295, 27. 12. 1901.

75 Budjenje narodne sviesti na Braču, Narodni list, jubilarni broj, 1. 3. 1912.

76 Nikša Stančıć, Jelsa na otoku Hvaru u vrijeme hrvatskog narodnog preporoda - o jednom modelu oblikovanja mediteranskih gradića i tipu nacionalne ideologije na hrvatskoj obali Jadrana u 19. stoljeću, u: Jelsa u hrvatskom narodnom preporodu Dalmacije, Zbornik radova, ur. Pavao Palaversić, Jelsa, 1994., $24-27$.

77 I. PERIĆ, Dalmatinski sabor, 221.

78 Javne zahvale, Narodni list, br. 59, 31. 7. 1886.

79 Priobćeno, prilog broju 16, Narodni list, br. 16, 22. 2. 1902. 
u tim se pismima već osjećala napetost koja će kasnije dobiti izraz u novinskim polemikama. ${ }^{80}$ Napetost jest eskalirala, ali je ipak Duboković tijekom polemike Didoliću izrazio nadu da će se ponovno na korist domovine kao i prije sastati i surađivati ako se obojica budu držala poštenja i morala, i budu živi. ${ }^{81}$

Osim sukoba Didolića i Dubokovića, Politeo također žali što je razvoj događaja prisilio njegova prijatelja Toma Didolića na dogovore s čistima i što je došlo do razdora između Toma Didolića i njegova bliskog prijatelja i rođaka ${ }^{82}$ dr. Ivana Štambuka. ${ }^{83}$ Izgleda da su takvi sukobi bili svojstveni Tomu Didoliću. To potvrđuje i Ivan K. Ostojić koji je nakon njegove smrti objavio sažet pregled korespondencije Toma Didolića, koji mu je bio kum i prijatelj. Na temelju Didolićevih pisama Ostojić ocjenjuje da je Tomo često znao biti ljut, nagao i naprasit, pa se upuštao u prepirke i polemike čak i sa sumartinskim franjevcima, mjesnim župnicima te svojim najbližim rođacima, ${ }^{84}$ što se može zaključiti i iz pojedinih njegovih konstrukcija u polemici s Radićem.

Politeo smatra pogrešnim što se pod svaku cijenu za kandidata otoka Brača htjelo istaknuti Bračanina; vidi to kao svojevrsni kampanilizam. Navodi kao primjer bivše zastupnike ovoga kotara, Stjepana Buzolića i Antu Nisitea, koji su bili izabrani samo zato što su porijeklom Bračani. Iako su obojica bili ugledni i uzorni pojedinci, Politeo smatra da se u sabornici nisu iskazali. Ako nije bilo moguće naći prikladnog kandidata u samom kotaru, Politeo smatra da ga se moglo tražiti izvan kotara kao u prošla vremena kada je Sinj birao Klaića, Knin, Dubrovnik i Šibenik Vrankovića, Imotska krajina Pavlinovića, a Makarska Kosta Vojnovića, dok se danas saborskim izborima pristupa administrativno. Smatra kako je načelo svakako zahtijevalo da se bira jedan narodnjak i jedan pravaš s obzirom na to da je pravaški element jak na Braču, Hvaru i Visu, pa mu je Narodna stranka trebala omogućiti da bude zastupljen u novom sazivu Dalmatinskog sabora. ${ }^{85}$

Već je prvi iz Politeove serije članaka izazvao odgovor splitskog Jedinstva, narodnjačkog glasila pod uredništvom Antuna Stražičića. Jedinstvo prigovara Politeu da se, u svrhu vlastite promocije, pojavi i zamuti vodu čim Hrvati krenu

80 12. 1901.

81 Častnom gospodinu Tomi Didoliću pok. Vicka, Jedinstvo, 7. 3. 1902.

82 Majka Toma Didolića mlađeg, Šima Didolić rođ. Štambuk (1827. - 1892.) bila je sestra Ivanova oca Ante Štambuka (1823. - ?). Vidi: Dario Štamвuк, Rodoslovlje, u: Štambuk: Povijest i rodoslovlje, Zbornik radova, ur. Maja Štambuk, Zagreb, 2019., 48, 59.

83 Odjeci dalmatinskih izbora, Novi list, br. 28, 4. 2. 1902.

84 I. K. Ostojić, Tomo Didolić, 111.

85 Odjeci dalmatinskih izbora, Novi list, br. 28, 4. 2. 1902. 
putem sloge. Politeovo stajalište o političkim prilikama i nesporazumu na Braču Jedinstvo pripisuje utjecaju Toma Didolića mlađeg, ${ }^{86}$ koji zaista jest, barem djelomično, utjecao na Politeovo gledište. ${ }^{87}$

Pored Politeovih članaka koji su pretežno načelnog sadržaja, uvid u pojedinosti prijepornog izbora u kotaru vanjskih općina Brača, Hvara i Visa dostupan je iz dopisa i priopćenja stranačkih glasila te korespondencija i brzojava pojedinih aktera.

Dogovornim izborom Ivčevića i Trumbića u kotaru vanjskih općina Splita, Trogira i Omiša, narodnjaci i pravaši najavili su političko zbližavanje. ${ }^{88}$ Unatoč tomu, stranačka glasila nisu se libila žustro komentirati sporna savezništva i trvenja u pojedinim kotarevima, u čemu nije bio izuzet ni izborni kotar vanjskih općina Brača, Hvara i Visa. Prvi iscrpniji osvrt na izborna događanja u ovom kotaru objavila je Prodanova Hrvatska kruna koja usprkos neuspješnom ishodu pozdravlja slogu čistih pravaša i biankinijevaca. U osvrtu od 21. prosinca 1901., objavljenom još prije Politeova prvog članka u Novom listu, Hrvatska kruna optužuje Hrvatsko političko društvo da je zagovaranjem kompromisa zavelo bračke birane birače. Po njihovoj je procjeni Brač mogao iznjedriti još šest do osam biranih birača pravaša više da je Društvo od početka zagovaralo samostalnu borbu, odnosno da nije najavljivalo slogu do koje naposljetku nije došlo. ${ }^{89}$ Don Juraj Biankini još je prije izbora prepoznao taj problem žaleći jer se dugo oklijevalo i kasno obznanilo samostalan izlazak Stranke prava na izbore što bi se moglo odraziti na loš rezultat. ${ }^{90} \mathrm{U}$ ovakvom razvoju događaja na izborima biranih birača na Braču, prema navodima Hrvatske krune, u Supetru i Nerežišćima birali su samo članovi izbornog povjerenstva. U Sutivanu nije izborima pristupilo ni deset birača, a u Pučišćima, u kojima je načelnik pravaš Ivo Marija Maroević, desetak birača izabralo je 7 biranih birača između kojih čak 4 narodnjaka, ${ }^{91} \mathrm{u}$ čemu je bolski pravaš Niko Petrić prepoznao Morpurgove prste. ${ }^{92}$ U predizborne kombinacije na Braču tako su ponovno, kao i 1895., bili uključeni narodnjaci iz splitskog kruga. Osim navodna Morpurgova utjecaja, nazire se to iz brzojava dr. Vicka Ivčevića Dubokoviću u kojem javlja da će šest pučiških

\footnotetext{
86 Izborna hronika, Spljet, Jedinstvo, br. 105, 31. 12. 1901.

87 I. K. Ostojić, Tomo Didolić, 133 - 134.

88 Izborna hronika, Jedinstvo, br. 102, 20. 12. 1901.

89 Naši dopisi, Hvar, Hrvatska kruna, 21. 12. 1901., novinski isječak dostupan u: HR-DAST, f. 617, Duboković, kut. 10, fasc. XXVIII.

$90 \quad$ SVKST, Arhiv Trumbić, M 452/10, Pismo J. Biankinija A. Trumbiću od 28. 11. 1901.

91 Naši dopisi; Hvar, Hrvatska kruna, 21. 12. 1901., novinski isječak dostupan u: HR-DAST, f. 617, Duboković, kut. 10, fasc. XXVIII.

92 SVKST, Arhiv Trumbić, M 476/10 - 12, Pisma N. Petrića A. Trumbiću od 1. 12. i 27. 11. 1901.
} 
birača podržati narodnjake Carića i Štambuka, osim načelnika Maroevića koji je pravaš. ${ }^{93}$ Hrvatska kruna još piše kako se brački narodnjaci nisu mogli između sebe dogovoriti kojega će kandidata istaknuti, što je moglo rezultirati slabijim odazivom biranih birača na izbor, pa se Niko Duboković zabrinuo da bi pravaši u takvim okolnostima mogli osvojiti oba mandata u kotaru. Duboković je, prema pisanju Hrvatske krune, presjekao spor i svojom inicijativom osigurao da narodnjaci uz Jurja Carića kao drugog kandidata istaknu liječnika u Jelsi dr. Ivana Štambuka. Iako se manevar provodio daleko od očiju javnosti, Hrvatska kruna piše kako iz pouzdanog izvora zna da je dr. Ivčević večer prije izbora priopćio viškom načelniku Topiću da su Carić i Štambuk narodnjački kandidati predodređeni za ovaj kotar. Navodno su na jutro izbora birani birači Visa i Komiže doputovali u Hvar s ceduljama na kojima su bila ispisana imena upravo njih dvojice. Hrvatska kruna tvrdi da je Štambuk jedva nagovoren na kandidaturu, ${ }^{94}$ no njegova je kandidatura neosporno bila ozbiljno iznesena, što je kasnije potvrdio i Duboković. ${ }^{95}$ Duboković je potom uvidio da sa Štambukom kao kandidatom neće moći osigurati dovoljno glasova biranih birača za svoju stranku, pa je odlučio žrtvovati pripremljenu kandidaturu svog prijatelja u korist bolskog načelnika Radića. Napravio je to noć prije izbora zaključivši da bi zbog neodlučnosti Pučišćana tijesnom razlikom mogla prevagnuti 4 birana birača iz Bola kojima je Ante Radić upravljao. Hrvatska kruna smatra da je Radić glasove bolskih biranih birača stavio na raspolaganje Dubokoviću i narodnjačkoj većini kako bi zauzvrat bio osobno izabran za saborskog zastupnika, iako je prije toga s Didolićem dogovarao kandidaturu svog brata Frane iza koje su stajali brački pravaši. Prema pisanju Hrvatske krune, u Hvar je na dan izbora pristiglo 43 od 44 bračkih biranih birača. Od tog broja pravaši su na svojoj strani imali svih 9 biranih birača iz Milne, svih 6 birača iz Selaca, 2 iz Supetra, 1 iz Sutivana i 1 iz Pučišća, dok je 6 neodlučnih pučiških birača čekalo da vide koja će strana imati većinu pa joj se po dobrom nepisanom običaju prikloniti. ${ }^{96}$ Takav scenarij pučiški je načelnik Maroević pismom najavljivao Anti Trumbiću, no ništa mu nije mogao jamčiti. ${ }^{97}$ Iz brzojava nekog od narodnjaka Dubokoviću uoči izbora iščitava se važnost podrške pučiških birača. Naime, u brzojavu piše da će narodnjaci istaknuti

93 HR-DAST, f. 617, Duboković, kut. 10, fasc. XXVIII., Brzojav N. Dubokoviću od 10. 12.1901.

94 Naši dopisi; Hvar, Hrvatska kruna, 21. 12. 1901., novinski isječak dostupan u: HR-DAST, f. 617, Duboković, kut. 10, fasc. XXVIII.

95 Častnom gospodinu Tomi Didoliću pok. Vicka, Jedinstvo, 7. 3. 1902.

96 Naši dopisi; Hvar, Hrvatska kruna, 21. 12. 1901., novinski isječak dostupan u: HR-DAST, f. 617, Duboković, kut. 10, fasc. XXVIII.

97 SVKST, Arhiv Trumbić, M 476/2, Pismo I. M. Maroevića A. Trumbiću od 2. 12. 1901. 
kandidature Carića i Štambuka, ako uspiju pridobiti glasove Pučišćana. ${ }^{98}$ Pravaši su po gornjem računu Hrvatske krune imali 19 od 37 bračkih birača ne računavši jednog supetarskog birača koji nije došao na izbor i neodlučne Pučišćane. No Duboković je na dan izbora s Boljanima i nekim pučiškim biračima proglasio da ima većinu birača otoka Brača na narodnjačkoj strani te je napomenuo kako već dugo godina postoji usmeni dogovor prema kojemu birači Hvara i Visa glasaju za kandidata kojeg proglasi bračka većina i obrnuto. ${ }^{99} \mathrm{Zbog}$ toga mu je Tomo Didolić prigovorio da se pozvao na onu staru praksu koju je namjeravao porušiti dok mu se činilo da mu neće ići u prilog. ${ }^{100}$ Izborom zastupnika u kuriji veleporeznika 21. prosinca u potpunosti su završeni izbori za Dalmatinski sabor 1901. godine. Ishod izbora u kotaru vanjskih općina Brača, Hvara i Visa tada je prokomentirao i Biankinijev Narodni list. U osvrtu piše kako svoju neslavnu pobjedu narodnjaci mogu zahvaliti jedino nepodopštinama i spletkama nekih narodnjačkih perjanica, optužujući pritom narodnjačke mešetare da su već prije izbora oblijetali oko bračkih biranih birača u Splitu. Proziva se poimenično jelšanskog načelnika Niku Dubokovića i nerežiškog načelnika Dubravčića da su interes stranke naposljetku ostvarili preko bolskog načelnika Ante Radića koji je navodno prije izbora ponavljao da će s pravašima ako oni budu birali njegova brata Franu Radića, a s narodnjacima ako će birati njega. ${ }^{101}$ Radić je kasnije takve navode ustrajno opovrgavao. ${ }^{102} \mathrm{Na}$ parobrodu Vis kojim se večer prije izbora plovilo prema Hvaru na izborno mjesto, zapodjenut je razgovor između Ante Radića i biranih birača Općine Selca - Mate Ostojića i Toma Didolića. Prema navodima Narodnog lista, u tom je razgovoru Mato Ostojić afirmativno govorio o potencijalnom kandidatu Frani Radiću. Tomo Didolić istaknuo je da je za njih Radićeva kandidatura obvezatna, ali ne može garantirati za milnarske birače (9) u njihovu odsustvu, već se s njima još valja dogovoriti. ${ }^{103}$ Te je navode Ante Radić također oštro opovrgavao $u$ kasnijoj polemici. ${ }^{104}$ Konačno su se stvari trebale utanačiti tik prije izbora, sljedećeg jutra u Hvaru, kada budu prisutni milnarski birači. Na dogovorenom sastanku Radić se ujutro nije pojavio, već je viđen u društvu narodnjaka Dubokovića i Dubravčića, na što je Duboković prišao

HR-DAST, f. 617, Duboković, kut. 10, fasc. XXVIII., Brzojav N. Dubokoviću od 8. 12. 1901.

Naši dopisi; Hvar, Hrvatska kruna, 21. 12. 1901., novinski isječak dostupan u: HR-DAST, f. 617, Duboković, kut. 10, fasc. XXVIII.

Izborno sgodopisje, Narodni list, br. 5, 15. 1. 1902.

Izborno sgodopisje; otok Brač, Narodni list, br. 103, 25. 12. 1901.

Izbor gosp. Antuna Radića, Jedinstvo, 3. 1. 1902., novinski isječak dostupan u: HR-DAST, f. 617, Duboković, kut. 10, fasc. XXVIII.

Izborno sgodopisje; otok Brač, Narodni list, br. 103, 25. 12. 1901.

Odgovori na otvoreno pismo Tome Didolića, 4. 
pravašima i uz Carićevu, najavio kandidaturu Ante Radića. Potom su Didolić i Ostojić okupili svoje birače u kavani, održali govore, pa u savezu s čistima istaknuli kandidature čistog pravaša don Ive Bojanića i Toma Didolića mlađeg. ${ }^{105}$

Duboković je kasnije objašnjavao da se dan uoči izbora ukrcao na parobrod za Hvar kako bi se uvjerio dogovara li se uistinu Didolić s čistima, na što su narodnjaci bili spremni kandidirati Antu Radića. Kaže da je odluku priopćio Didoliću na dan izbora, iako smatra da nije bio dužan, jer njemu osobno tijekom izbornog razdoblja nijedan pravaš s otoka nije predlagao da narodnjaci i pravaši složno biraju. ${ }^{106}$ Didolić mu odgovara ako mu je već bilo do sloge, zašto nije dogovorio s Radićem neka, umjesto Štambuka, pravaši i narodnjaci zajednički biraju njegova brata Franu Radića, pa da budu izabrani narodnjak Carić i pravaš Frano Radić, a ne narodnjak Carić i narodnjak Ante Radić. ${ }^{107}$

Što se tiče otvorenih pisama samih aktera, u svojstvu predstavnika Općine Selca i biranog birača na minulim izborima, Tomo Didolić ml.započeo je novinsku polemiku 4. siječnja 1902. pismom upućenim novoizabranom zastupniku Anti Radiću koje se rasteglo na četiri uzastopna broja Narodnog lista ${ }^{108}$ te kasnije bilo objelodanjeno u zasebnoj brošuri. ${ }^{109}$ Tomo Didolić ml. u rodnim je Selcima tada obnašao funkciju predsjednika društva Hrvatski sastanak i pjevačkotamburaškog društva Pavlinović te čast općinskog prisjednika i donačelnika, ${ }^{110}$ dok je mandat načelnika obnašao njegov rođak jasnog pravaškog opredjeljenja - Petar Didolić.

Tomo Didolić ml. u otvorenom pismu piše kako Radiću nakon okončanja izbora na Hvaru nije čestitao, nego mu je dao do znanja da prosvjeduje protiv njegova nekorektnog ponašanja i najavio objašnjenje za javnost. Didolić optužuje Radića da je htio još 1889., dok je njegova bolska općina imala svega 3 birana birača, neuspješno osujetiti izbor don Stjepana Buzolića. U travnju 1901. dok sabor nije bio ni raspušten, Ante Radić lobirao je kod Didolića za kandidaturu svog brata Franu, učitelja u Korčuli. Didolić je navodno tu

105 Izborno sgodopisje; otok Brač, Narodni list, br. 103, 25. 12. 1901. Zanimljiv je Dubokovićev navod kako je iz kvote čistih mandat u ovom kotaru bio rezerviran za don Ivu Prodana u slučaju neuspjeha njegove kandidature u vanjskim općinama Zadra, Paga i Raba. Vidi: Častnom gospodinu Tomi Didoliću pok. Vicka, Jedinstvo, 7. 3. 1902.

106 Odgovori na otvoreno pismo Tome Didolića, 3 - 6.

107 Priobćeno, prilog broju 16, Narodni list, br. 16, 22. 2. 1902.

108 Izborno sgodopisje, Narodni list, br. 2, 4. 1. 1902.; Izborno sgodopisje, Narodni list, br. 3, 7. 1. 1902.; Izborno sgodopisje, Narodni list, br. 4, 11. 1. 1902.; Izborno sgodopisje, Narodni list, br. 5, 15.1. 1902.

109 Otvoreno pismo gospodinu Anti Radiću načelniku u Bolu i novoizabranom zastupniku upravljeno od gospodina Tome Didolića, mladjega predstavnika obćine selačke i biranog birača, Zadar, 1902.

110 Priobćeno, Hrvatska kruna, br. 8, 29. 1. 1902. 
sugestiju u načelu prihvatio, ako bi se išlo za tim da kandidat za Brač bude Bračanin. Upozorio je pritom kako mjerodavni faktori na Braču ne prepoznaju dovoljno osobnost i zasluge Frane Radića. Didolić proziva Antu Radića da je na splitskom sastanku narodnjaka 22. studenog 1901. izjavio da će sa svojim biračima glasati za svog brata ako bi on bio pravaški kandidat za Brač, a ako ne, glasat će za narodnjake, iako je na sastanku dalmatinskih načelnika 16 . listopada u Splitu kao i svi prisutni zagovarao slogu hrvatskih stranaka. Poslije okončanja splitskog sastanka svih načelnika 16. listopada, poseban sastanak predstavnika općina Brača, Hvara i Visa održan je istog dana u gostioni viteza Dubokovića u Splitu s namjerom da se uglavi dogovor o kandidatima izbornog kotara vanjskih općina Brača, Hvara i Visa. Na tom sastanku Didolić nije htio sudjelovati naglasivši potrebu da se prvo konzultira sa svojim sumišljenicima. ${ }^{111}$ Prema Dubokovićevu kazivanju, na tom sastanku jednoglasno je izabran Juraj Carić za Hvar i Vis, ${ }^{112}$ dok se brački predstavnici nisu mogli dogovoriti oko svog kandidata. Nisu se mogli usuglasiti oko podrške kandidaturi supetarskog načelnika Ante Colombisa, pristaše Narodne hrvatske stranke. Naknadno su Bračani 4. prosinca na posebnom sastanku predstavnika bračkih općina u Supetru odlučili kandidata za svoj otok proglasiti na dan izbora na Hvaru. ${ }^{113}$

Na sastanku u Dubokovićevoj sobi navodno je dogovoreno da se narodnjaci neće pridržavati stare prakse prema kojoj se birani birači Hvara i Visa po pitanju kandidata za Brač trebaju prikloniti većini bračkih birača. O tome je na sastanku predstavnika bračkih općina u supetarskoj Slozi 4. prosinca 1901. govorio nerežiški načelnik Dinko Dubravčić. Pritom je kazao da je prijedlog potekao od viškog načelnika Topića uz argument da je stara praksa mogla imati smisla ranije, dok su viške općine bile autonomaške i nisu birale hrvatske birače te nisu sudjelovale u izboru narodnjačkih kandidata, a sada više nema. Dubravčićev izvještaj navodno je u Supetru potvrdio i sutivanski prisjednik Toma Ivanović. Na to su milnarski načelnik Mate Scarneo, pučiški načelnik Ivo Marija Maroević, predstavnik sutivanske općine Jerko Lukšić Carić i Tomo Didolić ml. kao predstavnik selačke općine odlučili da će nastojati izabrati dva pravaška zastupnika. Podrazumijevali su pritom Franu Radića kao jednog. Cilj su planirali ostvariti udruživanjem s čistim pravašima. ${ }^{114}$

111 Izborno sgodopisje, Narodni list, br. 2, 4. 1. 1902.

112 U kontekstu Dubokovićeve podrške Carićevoj kandidaturi, zanimljiv je podatak da su nekoliko godina nakon ovih izbora, točnije 25. 1. 1909., Niko Duboković i Juraj Carić postali tijesno povezani obiteljskim vezama jer je Dubokovićev sin Juraj oženio Carićevu kćer Eciju. Vidi: Kronika kapetana Nike Dubokovića, ur. Pavao Palaversić, Jelsa, 1998., 259.

113 Odgovori na otvoreno pismo Tome Didolića, 3 - 6.

114 Izborno sgodopisje, Narodni list, br. 3, 7. 1. 1902. 
Didolić dosljedno tvrdi da je čvrsto stajao iza kandidature Frane Radića. Na prvi pogled sumnju na njegov iskaz baca pismo koje je na Sv. Nikolu 1901., dakle nakon supetarskog sastanka predstavnika bračkih općina, poslao Trumbiću kazavši kako bi se u slučaju potrebe on i njegovi bili spremni zauzeti za kandidaturu Josipa Smodlake u ovom kotaru. ${ }^{115}$ Didolićevo pismo koje spominje Smodlaku nije sporno ako se uzme u obzir kako je kasnije pred Franu Radića bio otvoreno postavljen uvjet da se mora odreći kandidature ako je se odluči prihvatiti netko od stanovite trojice istaknutih pravaša. Jedan od te trojice bio je Josip Smodlaka. ${ }^{116}$

Zanimljivo je napomenuti kako je Didolić smatrao da načelnici i predstavnici općine nisu na supetarskom sastanku ovlašteni određivati kandidate umjesto već izabranih biranih birača, ${ }^{117} \mathrm{~s}$ čim se Ante Radić nije slagao. Nakon objeda u supetarskojgostioni Bore Rendića, Didolić se ipak složio s ostalim predstavnicima bračkih općina da se mogu dogovoriti o kandidatu, uz pripomenu da će to obvezati isključivo njih osobno kao birane birače. Didolić tvrdi kako je na sastanku predložio Franu Radića uz već spomenuti uvjet da se odrekne kandidature u slučaju da za kandidaturu u ovom kotaru interes pokažu neimenovana trojica uglednika te da se odrekne učiteljske službe s obzirom na to da mu pojedinci službu pripetavaju kao otegotnu okolnost. ${ }^{118} \mathrm{Da}$ je Didolić uistinu tako predložio doznajemo iz pisma Frane Radića Luji Marunu. U njemu Frano šalje prijepis pisma poslanog bratu Anti te otkriva podatak da su Didolićeva neimenovana trojica Juraj Biankini, Ante Trumbić i već spomenuti Josip Smodlaka. Iz istog pisma doznaje se da je Frano Radić tri dana prije izbora pisao bratu kako bi svoju kandidaturu u slučaju potrebe bio spreman prepustiti samo don Jurju Biankiniju. Ako bude izabran, stupio bi u Biankinijev pravaški klub zagovarajući bratsku slogu hrvatskih stranaka. ${ }^{119}$

Što se Didolićeve suradnje s čistima tiče, dr. Ivan Štambuk kasnije je prigovorio Tomu Didoliću da je još u studenom osuđivao Prodana i prodanstvo te Franka i frankovluk, a onda se preko noći povezao s čistima i ušao u rat sa strankom kojoj je donedavno pripadao i čijom se tradicijom ponosio. Navodno se Didolić povezao s čistima preko jednog jelšanskog posrednika, ${ }^{120}$ vjerojatno svećenika

115 SVKST, Arhiv Trumbić, M 476/8, Pismo T. Didolića ml. A. Trumbiću od 6. 12. 1901.

116 Muzej hrvatskih arheoloških spomenika, Korespondencija Frano Radić - Lujo Marun (dalje: MHAS + D), D266, Pismo F. Radića Luji Marunu 31. 12. 1901.

117 SVKST, Arhiv Trumbić, M 476/9, Pismo T. Didolić ml. Anti Trumbiću od 3. 12. 1901.

118 Izborno sgodopisje, Narodni list, br. 3, 7. 1. 1902.

119 MHAS, D266, Pismo F. Radića Luji Marunu 31. 12. 1901.

120 Velecijenjeni gosp. uredniče!, Jedinstvo, 11. 3. 1902., novinski isječak dostupan u: HR-DAST, f. 617, Duboković, kut. 10, fasc. XXVIII. 
Vicka Gamulina, ${ }^{121}$ pa sklopio sporazum s komiškim župnikom Bojanićem, a svog je posrednika izvijestio da glasove koji nedostaju nastoji pridobiti agitacijom. Pridobivanje glasova agitacijom među biranim biračima Štambuk naziva političkim pazarom pod čime se podrazumijeva izborni ishod u kojem primjerice birani birač Narodne stranke glasa za pravaše ili obratno. Po svemu sudeći, takve su pojavnosti načelno izazivale moralno zgražanje političke elite, iako se arhitektura potrebne većine u tijesnim odnosima snaga često temeljila upravo na takvoj agitaciji. ${ }^{122}$ Kao primjer može se navesti pismo u kojem pravaš Ante Visković iz Gdinja, svjestan takve mogućnosti, piše da su njihova dvojica biranih birača sebični ljudi, pa bi se na dan izbora moglo dogoditi da ih druga strana na biralištu pridobije za sebe. ${ }^{123}$

Didolić nije krio da su brački pravaši ušli u pregovore s čistim pravašima $s$ otoka Hvara, svjesni kako sami neće imati dovoljno glasova za eventualnu većinu. Dogovorili su da će birati jednog umjerenog pravaša biankinijevca i jednog čistog. ${ }^{124}$ Postoji pismo koje čak spominje opciju prema kojoj su čisti bili spremni u ovom kotaru podržati i dva umjerena pravaša, ako bi biankinijevci njih podržali u nekim drugim kotarevima, no očito ova mogućnost nije zaživjela. ${ }^{125}$ Tomo Didolić dosljedno tvrdi da su brački pravaši kao pravaškog kandidata čitavo vrijeme računali na Franu Radića, uz rečene uvjete. Nisu ni mogli postupati drugačije jer su bili svjesni da im ni sva 4 bolska birana birača neće biti dovoljna za pobjedu, a na njih mogu računati isključivo u slučaju kandidature njihova sumještanina Frane Radića. Na parobrodu za Hvar Didolić se nije htio dogovarati u ime Milnarana i njihova načelnika Scarnea u njihovu odsustvu, posebice stoga što je znao da su Milnarani bili sumnjičavi prema namjerama Ante Radića zbog njegova držanja na sastanku narodnjaka. ${ }^{126}$ Pri spomenu njegove kandidature u listopadu je prema njemu bio sumnjičav i bolski pravaš Niko Petrić pišući Trumbiću da je Ante Radić vladino dijete. ${ }^{127} \mathrm{U}$ tom smislu bile su sporne tvrdnje Ante Radića da mu je Mate Scarneo 12. studenog posredstvom tajnika svoje općine Poklepovića nudio kandidaturu, na što je on ipak preporučio svog brata. ${ }^{128} \mathrm{Na}$ tragu Radićeve izjave Niko je Duboković potvrdio da je Scarneo zaista poticao Antu Radića na

121 Odgovori na otvoreno pismo Tome Didolića, 8.

122 Velecijenjeni gosp. uredniče!, Jedinstvo, 11. 3. 1902.

123 SVKST, Arhiv Trumbić, M476/3, Pismo A. Viskovića P. Ruževiću od 2. 12. 1901.

124 Izborno sgodopisje, Narodni list, br. 4, 11. 1. 1902.

125 SVKST, Arhiv Trumbić, M 476/1, Pismo J. Dobrovića A. Trumbiću od 8. 12. 1901.

126 Izborno sgodopisje, Narodni list, br. 5, 15. 1. 1902.

127 SVKST, M 451/46, Pismo N. Petrića A. Trumbiću od 21. 10. 1901.

128 In atto di imparzialita, Il Dalmata, br. 11, 8. 2. 1902.; Izbor gosp. Antuna Radića, Jedinstvo, 3.1. 1902. 
kandidaturu, i to na sastanku u Splitu u njegovoj gostioni. ${ }^{129}$ Unatoč svjedocima, Boljanima Dinku Matulića i Anti Turketu, koji su izjavama u Narodnom listu dali za pravo Dubokoviću i Anti Radiću, ${ }^{130}$ milnarski općinski tajnik Poklepović nije se predavao. Reagirao je optuživanjem svjedoka za nepoštenu riječ tvrdeći kako je kandidaturu Radiću predložio još prije sastanka narodnjaka 22. studenog u Splitu i prije sastanka predstavnika bračkih općina u Supetru 4. prosinca, a poznato je da su ti sastanci stvari usmjerili novim tokom. Poklepović niječe da je ikada kandidaturu Radiću nudio u ime načelnika Scarnea. ${ }^{131}$

Ante Radić, s druge strane, poriče da je ikada zagovarao vlastitu kandidaturu za što ga optužuju iz pravaškog tabora. Tvrdi da je bio spreman pod određenim uvjetima podržati čak i kandidaturu nekog drugog odličnog pravaša umjesto svog brata, što daje dozu realnosti i smisla Didolićevim promišljanjima i uvjetima Frani Radiću o odricanju od kandidature ako se odluče u ovom kotaru kandidirati Biankini, Trumbić ili Smodlaka. ${ }^{132}$

Kako god, Didolić objašnjava da je unatoč njihovu nepovjerenju prema Anti Radiću, Milnaranima tik uoči izbora uspio objasniti važnost 4 glasa bolskih biranih birača nakon čega su pristali podržati kandidaturu Frane Radića. U kontekstu jedne rasprave o Scarneovu zagovaranju kandidature Josipa Smodlake i protivljenja Ante Radića istoj, Radić je navodno izjavio da je on Hrvat koji ne pripada nijednoj stranci i koji se ne da zanijeti idealizmom i paragrafiranim programima, što je kod Didolića bilo probudilo sumnju u njegovu iskrenost, kao i činjenica da je Radić do sastanka u Supetru zagovarao neka se istakne kandidat za Brač, da bi na sastanku promijenio mišljenje i predložio da se kandidat dogovori na Hvaru na licu mjesta. To je post festum Didolića navelo na razmišljanje kako je Radić već tada razmišljao o svojoj kandidaturi, a ne o kandidaturi svog brata.

Tomo Didolić ml. u otvorenom pismu osobito zamjera Radiću i Dubokoviću povučene poteze koji su bili u suprotnosti s njihovim stavom proklamiranim 16. listopada na sastanku načelnika u Splitu. Kao ključan motiv neskrivene suradnje s čistima navodi događanja na užem sastanku predstavnika općina Brača, Hvara i Visa u Dubokovićevoj gostioni nakon splitskog sastanka, gdje je navodno bila donesena odluka o rušenju stare prakse na koju su se onda upravo narodnjaci pozvali na dan izbora, a da nisu pri utvrđivanju većine bračkih birača pozvali sve predstavnike selačkih, milnarskih i pučiških birača. Didolić smatra da su se jednostavno mjesni odbori trebali dogovoriti na način da u kotaru bude izabran

129 Odgovori na otvoreno pismo Tome Didolića, 4.

130 Izborno sgodopisje; Bol, Narodni list, br. 3, 7. 1. 1902.

131 Izborno sgodopisje; Milna, Narodni list, br. 6, 18. 1. 1902.

132 Odgovori na otvoreno pismo Tome Didolića, 9. 
jedan narodnjak i jedan pravaš. Didolić na koncu svog priopćenja poziva Radića da se zahvali na mandatu i završava pismo uz poklik: Doli nedostojni. ${ }^{133}$

Ante Radić u svojim odgovorima Didoliću, objavljenima u Jedinstvu i tiskanima u zasebnoj brošuri nakon konzultiranja s Dubokovićem, ${ }^{134}$ kao ključnu točku svoje obrane iznosi tezu da Didolić i njegovi suradnici nisu nikad iskreno podržavali kandidaturu njegova brata Frane. ${ }^{135} \mathrm{U}$ pismima Frani Radiću Antinu su tezu potvrđivali i ostali bolski birani birači. Neki od njih čak su Franu pisali da su osobno vidjeli pismo u kojemu Tomo Didolić piše da se neće Franu Radića birati zastupnikom. ${ }^{136}$ Ante Radić navodi primjer Didolićeva prijatelja i selačkog biranog birača Mate Ostojića koji je navodno istupio protiv kandidature Frane Radića, uz izjavu da on neće dogovor s biračima Narodne stranke jer su mu bliži čisti pravaši nego narodnjaci. Ante Radić smatra da su time pravaški birači s Brača zapravo iznevjerili dogovor o sporazumnom izboru Jurja Carića i Frane Radića. ${ }^{137} \mathrm{Na}$ te je optužbe posjednik i pjesnik Mato Ostojić istupio poprilično oštro protiv Radića u Narodnom listu optužujući ga za laganje i obasipajući ga uvredama. Ostojić piše da je zaista kazao da su mu čisti pravaši bliži od narodnjaka, i to se ne ustručava priznati jer smatra da je sadašnje narodnjaštvo najpogubniji zlotvor brvatskog naroda u Dalmaciji. ${ }^{138}$ Istu frazu upotrijebio je $u$ pismu svom bliskom prijatelju Anti Tresiću Pavičiću. ${ }^{139}$ Potajno je Mato Ostojić, zajedno s bratom Nikolom, kroz listopad i studeni zagovarao kod Trumbića i Petra Didolića kandidaturu pravaša Ante Tresića Pavičića, no na temelju sačuvanih pisama ne može se sa sigurnošću tvrditi bi li se Tresićeva kandidatura odnosila na kotar vanjskih općina Brača, Hvara i Visa. ${ }^{140}$ Mato Ostojić javno je negirao optužbe Ante Radića, tvrdeći da sposobnosti i vrline Frane Radića cijeni i uvažava te ga poštuje kudikamo više od brata Ante. Nakon izbora birani birači iz Bola obavijestili su Franu kako je Ostojić na parobrodu govorio o Franinim vrlinama, no isto tako zaključio da ga vodi sebičnost, odnosno želja da se

133 Izborno sgodopisje, Narodni list, br. 5, 15. 1. 1902.

134 HR-DAST, f. 617, Duboković, kut. 10, fasc. XXVIII., Pismo A. Radića N. Dubokoviću od 13. 2. 1902.

135 Odgovori na otvoreno pismo Tome Didolića, 6 - 12.

136 MHAS, D266, Pismo F. Radića Luji Marunu 31. 12. 1901.

137 Izbor gosp. Antuna Radića, Jedinstvo, 3. 1. 1902., novinski isječak dostupan u: HR-DAST, f. 617, Duboković, kut. 10, fasc. XXVIII.

138 Gospodinu Anti Radiću obćinskomu načelniku u Bolu na Braču, Narodni list, br. 13, 12. 2. 1902.

139 Hrvatska - Hrvatski državni arhiv, Zagreb (dalje: HR-HDA), fond 834, Tresić Pavičić Ante (dalje: Tresić Pavičić), kut. 2, omot 16, pismo M. Ostojića A. Tresiću Pavičiću od 29. 11. 1901.

140 HR-HDA, f. 834, Tresić Pavičić, kut. 2, omot 16, pismo M. Ostojića A. Tresiću Pavičiću od 29. 11. 1901.; HR-HDA, f. 834, Tresić Pavičić, kut. 2, omot 10, Pisma N. Ostojića A. Tresiću Pavičiću od 22. 10., 8. 11. i 26. 11. 1901 . 
situira i u gradu odgoji svoje petero djece te doveo u pitanje njegovo pravaško opredjeljenje. Ostojić je do takvog zaključka došao zahvaljujući zajedničkom im prijatelju fra Luji Marunu koji mu je govorio o Radićevoj ekonomskoj situaciji, što je Radić Marunu zamjerio. Iz dopisivanja Frane Radića i Maruna može se posredno zaključiti da je ekonomska i obiteljska situacija zaista bila jedan od motiva za kandidaturu Frane Radića, iako ne ni presudni ni ključni. ${ }^{141}$ Ostojić se prilikom istupa u Narodnom listu uvredama okomio i na urednika narodnjačkog glasila Jedinstva Antuna Stražičića, kojeg naziva vrtikapom ${ }^{142}$ aludirajući na njegovo političko konvertitstvo. ${ }^{143}$ Stražičić Ostojiću nije ostao dužan te u odgovoru navodi da ga se uplelo u polemiku o izboru Radića samo zato što je jednom kritizirao Ostojićev književni rad, što je Ostojiću smetalo jer boluje od uobraženja. Stražičić ne štedi Matu Ostojića nazivajući ga prostim književnim kupusarom i bračkom mazgom. ${ }^{144}$

U Dubokovićevu odgovoru Tomu Didoliću nailazimo na optužbu da je Didolić imao pripremljenog tajnog kandidata. ${ }^{145}$ Štoviše, Radić optužuje Toma Didolića da je uoči sastanka u Supetru spominjao mogućnost vlastite kandidature, pa čak i kandidature svog rođaka i selačkog načelnika Petra Didolića. Didolić je to navodno povjerio svom rođaku dr. Ivanu Štambuku. ${ }^{146} \mathrm{Iz}$ Trumbićeve korespondencije doznajemo da je kandidatura Petra Didolića kao pravaša zaista u jednom trenutku bila na stolu. Preporučio ju je pučiški načelnik Maroević, ${ }^{147}$ a interno ju je spomenuo i Trumbić. ${ }^{148}$ Koliko je poznato na temelju dostupne arhivske građe, ona ipak nije ozbiljno uzeta u obzir. Što se tiče tajnog kandidata, Tomo Didolić ml. priznaje da ga je imao u pripremi, ali mu nije jamčio kandidaturu. Kontaktirao ga je tri dana prije izbora da vidi bi li prihvatio kandidaturu ako bi njegovo ime došlo u kombinaciju na dan izbora, što je Didolić smatrao vjerojatnim. ${ }^{149}$ Taj tajni kandidat bio je Petar Biankini, brat don Jurja Biankinija. Taj podatak doznajemo iz jednog Didolićeva pisma Trumbiću. ${ }^{150}$ Didolić naposljetku nije posegnuo za kandidaturom Petra Biankinija. S druge

141 MHAS, D266, Pismo F. Radića Luji Marunu 31. 12. 1901.

142 Gospodinu Anti Radiću obćinskomu načelniku u Bolu na Braču, Narodni list, br. 13, 12. 2. 1902.

143 O političkom konvertitstvu Antuna Stražičića vidi: Stjepan Ćosıć, Antun Stražičić i dubrovački Srbi katolici, u: Dubrovački koluri: uspon i pad srbokatolika, ur. Stjepan Ćosić, Dubrovnik, 2018.

144 Dopisnica uredništva, Jedinstvo, 14. 2. 1902., novinski isječak dostupan u: HR-DAST, f. 617, Duboković, kut. 10, fasc. XXVIII.

145 Odgovori na otvoreno pismo Tome Didolića, 4.

146 Odgovori na otvoreno pismo Tome Didolića, 8 - 9.

147 SVKST, Arhiv Trumbić, M 476/2, Pismo I. M. Maroevića A. Trumbiću od 2. 12. 1901.

148 SVKST, Arhiv Trumbić, M 476/7, Pismo P. Didolića A. Trumbiću od 28. 11. 1901.

149 Priobćeno, prilog broju 16, Narodni list, br. 16, 22. 2. 1902.

150 SVKST, M 476/8, Pismo T. Didolića ml. A. Trumbiću od 6. 12. 1901. 
strane, Duboković je odlučio Antom Radićem zamijeniti dr. Štambuka za kojeg je cijelo vrijeme agitirao, kada se uvjerio da bolski birači neće glasati za njega zbog čega bi mogao ostati bez potrebne većine. ${ }^{151}$

U otvorenom pismu Radić zaključuje da je Tomu Didoliću bilo poznato kako većina pučiških birača i svi bolski birači neće glasati za kombinaciju od dvojice pravaša i da nijedna kombinacija osim Carića i Frane Radića neće imati većinu bračkih birača na svojoj strani. Radićeva tvrdnja argument je u prilog logici objašnjenja Toma Didolića: bez dogovora s Radićem, koji Ante Radić negira, ne bi uopće imalo smisla kompromitirati se suradnjom s čistima ni zagovarati dvije pravaške kandidature. U Radićevim odgovorima možemo pronaći tvrdnju da je Didolić mislio da je svojim izlaskom iz višegodišnjeg političkog mrtveža i uskakanjem u pravaški tabor prekalupio čitavi Brač i čitavi izborni kotar što se temeljem izbornog rezultata nije pokazalo kao slučaj. ${ }^{152}$ Radić je time aludirao na Didolićevu objavu u Narodnom listu kojom pristaje uz proglas Odbora Hrvatskog političkog društva o samostalnom izlasku na izbore te poziva Bračane da ga slijede. ${ }^{153}$ Ta njegova politička reaktivacija, prema Petru Didoliću, bila je posljedica Trumbićeva utjecaja. ${ }^{154}$ Poput Didolića, i Ante Radić u polemici je posezao za poprilično uvredljivim konstrukcijama. Tako piše: „Kad bih ja mario što mi u politici privikuje jedan Tomo Didolić mlađi, bio bih gori od Toma Didolića mlađega, a od toga ukloni me Bože. “155

Kapetan Niko Duboković koji nije bio sklon novinskim polemikama ipak se i sam javno oglasio na Didolićeve prozivke. Odgovornost za nepridržavanje odluke sastanka načelnika u Splitu 16. listopada posredno prebacuje na Trumbića koji je navodno tražio previše mandata za pravaše i time odbacio slogu. ${ }^{156}$ Tomo Didolić stao je u njegovu obranu tvrdeći da je Trumbić kazao da se na sastanku ne može zaključiti ništa o sjedinjenju stranaka s obzirom na to da sastanak zbog toga nije sazvan, a što se izbora tiče, zalagao se da se provedu u bratskoj slozi svih Hrvata. Didolić također podsjeća Dubokovića na sastanak koji su njih dvojica $s$ Trumbićem održali u Troccolijevoj kavani dan uoči sastanka narodnjačkih načelnika i zastupnika u Splitu 22. studenog. Tada je Trumbić naglasio da bi na sastanku svi narodnjački načelnici trebali zahtijevati da sastanak najprije

151 Naši dopisi, Hvar, Hrvatska kruna, 21. 12. 1901.

152 Odgovori na otvoreno pismo Tome Didolića, 7.

153 Izborna hronika, Jedinstvo, br. 97, 3. 2. 1901.

154 SVKST, Arhiv Trumbić, M 476/6, Pismo P. Didolića A. Trumbiću od 1. 12. 1901.

155 Odgovori na otvoreno pismo Tome Didolića, 6 - 12.

156 Častnom gospodinu Tomi Didoliću pok. Vicka, Jedinstvo, 7. 3. 1902.; Odgovori na otvoreno pismo Tome Didolića, 3 - 6. 
usvoji zaključak sastanka svih hrvatskih načelnika od 16. listopada bez da utvrđuje koliko zastupnika po broju ima dobiti koja stranka. Prema Didolićevu kazivanju, Trumbić je smatrao da bi Narodna hrvatska stranka trebala izabrati izborni odbor koji će odlučivati o izbornim poslovima. No stvari se nisu odvile po Trumbićevim naputcima i željama, već suprotno. ${ }^{157}$ Petar Didolić preporučio je Trumbiću uoči tog improviziranog sastanaka Toma Didolića, Trumbića i Dubokovića, neka nastoji da dođe do složnog biranja u kotaru vanjskih općina Brača, Hvara i Visa na način da se izabere jedan narodnjak i jedan pravaš jer smatra da će svi načelnici na to pristati osim supetarskog Colombisa. ${ }^{158}$ Tom je prigodom Petar Didolić Trumbiću još napisao da je njegov rođak Tomo koji dolazi na sastanak čvrsto odlučio utjecati na narodnjake i pravaše kako bi se pridržavali listopadskog zaključka načelnika u Splitu. U istom pismu apelira na Trumbića neka pripazi na naivnost Toma Didolića, neka mu da instrukcije kako i o čemu razgovarati s narodnjacima da se ne bi olako upustio u predlaganje imena potencijalnih pravaških kandidata što u toj fazi nije bilo poželjno. ${ }^{159}$

Iako Trumbićeva korespondencija upućuje na Didolićevu težnju k slozi, Duboković optužuje Toma Didolića da se počeo dogovarati s čistima ignorirajući jednoglasno donesenu odluku o kandidaturi Jurja Carića za Hvar i Vis. Tomo Didolić ml. upozorava na kronologiju događaja tvrdeći da je počeo pregovarati s čistima tek nakon što je uvidio da narodnjaci u ovom kotaru ne žele nastupiti složno. ${ }^{160}$ Juraj Biankini još je početkom studenog 1901. pisao Trumbiću da narodnjaci, odnosno dr. Vicko Ivčević, ne pristaju pravašima ustupiti po jednog zastupnika u određenim kotarevima, navodeći među njima izričito i kotar vanjskih općina Brača, Hvara i Visa. ${ }^{161}$ Kako bi dokazao da su narodnjaci pod svaku cijenu htjeli u ovom kotaru izabrati dva narodnjaka, Didolić u prilog svojoj argumentaciji spominje susret sa splitskim narodnjakom Vidom Morpurgom dan uoči izbora. Morpurgo mu je tom prilikom navodno priznao kako narodnjaci uopće nisu htjeli kompromis s pravašima u ovom kotaru. Pozvao je Tomu Didolića i njegove neka izaberu Ivana Štambuka ili Antu Nisitea, svoje sumještane, no ipak narodnjake na što je Didolić odgovorio da tako ne može jer se vode načelom. ${ }^{162}$ Da narodnjaci ne žele složan nastup Didolić je zaključio i iz Dubokovićeva prijedloga dan uoči sastanka narodnjačkih načelnika 22. studenog u Splitu. Na

157 Priobćeno, prilog broju 16, Narodni list, br. 16, 22. 2. 1902.

158 SVKST, Arhiv Trumbić, M 452/21, Pismo P. Didolića A. Trumbiću od 18. 11. 1901.

159 SVKST, Arhiv Trumbić M 452/22, Pismo P. Didolića A. Trumbiću od 21. 11. 1901.

160 Odgovori na otvoreno pismo Tome Didolića, 4.

161 SVKST, Arhiv Trumbić, M 452/8, Pismo J. Biankinija A. Trumbiću od 9. 11. 1901.

162 Priobćeno, prilog broju 16, Narodni list, br. 16, 22. 2. 1902. 
parobrodu mu je Duboković tada priznao da će nastojati da se na sastanku za otok Brač prihvati kandidatura dr. Ivana Štambuka, Didolićeva rođaka. Didolić mu je na to odgovorio da bi Selca podržala Štambukovu kandidaturu kad bi se u kotaru biralo jednog pravaša i jednog narodnjaka. Ako bi se htjelo birati dvojicu narodnjaka, pa makar među njima bio i Selčanin Štambuk, selački birani birači, redom pravaši, bili bi protiv iz političkih razloga, ${ }^{163}$ bez obzira na to što je Duboković smatrao dr. Ivana Štambuka osobom koja ima mnogo dodirnih točaka sa Strankom prava. Naposljetku je Duboković pragmatički ustvrdio da se nije držao rezolucija sa sastanka hrvatskih načelnika od 16. listopada 1901. jer one nisu bile ni prihvaćene. Stoga se nije smatrao dužnim zagovarati kandidaturu osoba koje pripadaju drugim strankama. ${ }^{164}$

U zakašnjeloj fazi rasprave oglasio se dr. Ivan Štambuk osobno. Tom prilikom objašnjava kako je nastojao otkloniti od sebe ponuđeni mandat za koji nije imao volje, vremena, ni spreme. Međutim, nesporazum između zagovornika kandidature Frane Radića i zagovornika kandidature Ante Colombisa stvorio je potrebu da se iznađe treći, neutralni kandidat. U takvim je okolnostima uvjetno pristao na kandidaturu ako bi se pokazalo da ni s jednim drugim kandidatom Narodna hrvatska stranka ne bi mogla ostvariti izborni uspjeh. ${ }^{165}$ Dok se nije znalo hoće li Štambuk prihvatiti kandidaturu, iako se Colombis odrekao u njegovo ime, kao o zamjenskoj opciji razmišljalo se o ravnatelju realke u Zadru i bivšem zastupniku Anti Nisiteu. ${ }^{166}$ Štambukova kandidatura ovisila je o kristaliziranju većine bračkih birača. $S$ obzirom na to da se taj proces pokazao neizvjesnim i potencijalno nepovoljnim za narodnjake, njegova kandidatura u kotaru vanjskih općina Brača, Hvara i Visa nije istaknuta. ${ }^{167}$ U konačnici je Štambuk osvanuo kao izabrani saborski zastupnik u izborništvu veleporeznika splitskog okružja, iako je dan prije izbora brzojavio Dubokoviću neka se njegova kandidatura izmijeni. ${ }^{168}$ Štambuk ne pokušava obrazložiti svoj izbor u kuriji veleporeznika. Piše kako ne mari istraživati je li tamo predložen u nedostatku drugih kandidata ili kako bi mu se nadoknadio tobožnji neuspjeh u kotaru

163 Priobćeno, prilog broju 16, Narodni list, br. 16, 22. 2. 1902.

164 Častnom gospodinu Tomi Didoliću pok. Vicka, Jedinstvo, 7. 3. 1902., novinski isječak dostupan u: HR-DAST, f. 617, Duboković, kut. 10, fasc. XXVIII.

165 Velecijenjeni gosp. uredniče!, Jedinstvo, 11. 3. 1902., novinski isječak dostupan u: HR-DAST, f. 617, Duboković, kut. 10, fasc. XXVIII.

166 HR-DAST, f. 617, Duboković, kut. 10, fasc. XXVIII., Pismo D. Dubravčića N. Dubokoviću od 5. 12. 1901.

167 HR-DAST, f. 617, Duboković, kut. 10, fasc. XXVIII., Brzojav N. Dubokovića D. Dubravčiću.

168 HR-DAST, f. 617, Duboković, kut. 10, fasc. XXVIII., Brzojav I. Štambuka N. Dubokoviću od 20. 12. 1901. 
vanjskih općina Brača, Hvara i Visa. Prihvatio je mandat koji su mu dogovorno u splitskom veleporezničkom okružju ponudili narodnjaci i pravaši u cilju sloge hrvatskih stranaka. ${ }^{169}$ Iako su i neki Trumbićevi pouzdanici za dr. Štambuka tvrdili da je pošten čovjek, više pravaš nego narodnjak, ${ }^{170}$ Didolići su se do kraja principijelno protivili izboru narodnjaka Ivana Štambuka. Netom prije održavanja izbora u kuriji veleporeznika Petar Didolić brzojavio je Trumbiću ako se već ne može kandidirati odvjetnika Antu Štambuka, pravaša, neka se pokuša kandidirati bivšeg zastupnika Antu Nisitea. No bilo je odlučeno da se podrži dr. Ivana Štambuka, ${ }^{171}$ jer je sporazumom o zajedničkom izlasku na izbore narodnjaka i pravaša u kotaru vanjskih općina Splita, Trogira i Omiša još prije bilo određeno da će pravaši u izborništvu veleporeznika splitskog okružja podržati predloženike Narodne hrvatske stranke. ${ }^{172}$ Petrov rođak Tomo Didolić Štambukov je izbor tumačio kao pobjedu sile jednog čovjeka misleći na Dubokovića. Štambuk mu je takve stavove zamjerio. ${ }^{173}$

Dakle, dr. Ivan Štambuk naposljetku se javno oglasio. Za razliku od njega, Frano Radić nije uopće javno istupao po pitanju izbora, iako se konstantno $\mathrm{u}$ javnosti nabacivalo njegovim imenom. Išlo se toliko daleko da je Didolić u zadnjem otvorenom pismu Antu Radića nazvao nedostojnim bratom Frane Radića. ${ }^{174} \mathrm{Na}$ sreću, stajališta Frane Radića o ovom pitanju mogu se rekonstruirati iz pisama koja je Radić slao svom prijatelju i suradniku, arheologu fra Luji Marunu s kojim ga je vezalo bavljenje starinama i uredništvo časopisa Starohrvatska prosvjeta. Radiću je zaista bilo stalo do obnašanja časti narodnog zastupnika, koju je već neuspješno pokušao izboriti 1889. godine. Svoju kandidaturu u kotaru vanjskih općina Brača, Hvara i Visa ovaj je put pomno osmislio. Najavio je namjeru kandidiranja fra Luji Marunu još početkom siječnja 1901. godine dok su izbori još bili daleko. ${ }^{175}$ Kada je počet kom listopada boravio u Bolu, nije otišao u Selca jer je doznao kako mu je Didolić navodno posve sklon i nije ga potrebno dodatno uvjeravati. ${ }^{176}$ Nakon što mu je brat Ante javio da su mu narodnjaci na splitskom sastanku u studenom zamjerali da je klerikalac, svoju je poziciju nastojao ojačati posredstvom Luje Maruna od

169 Velecijenjeni gosp. uredniče!, Jedinstvo, 11.3. 1902.

170 SVKST, Arhiv Trumbić, M 476/5, Pismo V. Bucenića A. Trumbiću od 5.12. 1901.

171 SVKST, Arhiv Trumbić, M 473/17, Brzojav P. Didolića A. Trumbiću 19. 12. 1901.

172 SVKST, Arhiv Trumbić, M 474/2 - 3, Zapisnik o izbornom sporazumu.

173 Velecijenjeni gosp. uredniče!, Jedinstvo, 11.3. 1902., novinski isječak dostupan u: HR-DAST, f. 617, Duboković, kut. 10, fasc. XXVIII.

174 Priobćeno, prilog broju 16, Narodni list, br. 16, 22. 2. 1902.

175 MHAS, D249, Pismo F. Radića L. Marunu 3. 1. 1901.

176 MHAS, D260, Pismo F. Radića L. Marunu 6. 10. 1901. 
kojeg je tražio neka ga preporuči pravaškim zastupnicima Biankiniju i Periću, pa da oni brzojavljanjem po otocima podupru njegovu kandidaturu. ${ }^{177}$

Kad je saznao neočekivan ishod izbora na Hvaru, krivnju je prvotno u potpunosti svalio na Toma Didolića, kojeg je do tada iznimno cijenio. Informiran prvenstveno preko bolskih biranih birača, pisao je Marunu kako je Didolić skrivio pravaški neuspjeh da bi udovoljio vlastitoj ambiciji i inatu. Stoga je njegov brat Ante bio primoran primiti se mandata da bi spasio kotar od sramote. ${ }^{178}$ Frano Radić s vremenom je postao kritičniji prema ponašanju svoga brata. $\mathrm{Na}$ Staru godinu 1901. piše Marunu kako je ovom prigodom morao popiti gorku čašu razočarenja o bratovoj ljubavi i iskrenosti, iako ni sam ne zna kome vjerovati jer se svi kunu da pišu živu istinu, dok iznose poprilično različite verzije događaja. Poslao je nakon izbora bratu Anti pismo prigovorivši mu da je s njim neiskreno postupao. Brat mu nije ništa odgovorio. S obzirom na to da nije više dobio vijesti od doma, zaključio je da su u obitelji uspostavljeni napeti odnosi. ${ }^{179}$ Osobno je teško proživljavao događanja uoči i nakon izbora. Smatrao je da se svatko želi njime okoristiti, iako ga svi načelno hvale. Dugotrajne novinske prepiske o izborima u kotaru vanjskih općina Brača, Hvara i Visa, u kojima se stalno pisalo o njemu, uzrujavale su ga i ometale u radu, no ipak je pomoću njih želio doznati istinu, s obzirom na to da je počeo u svih sumnjati. ${ }^{180}$ Krajem siječnja 1902. otišao je u rodni Bol kako bi popravio odnos s bratom. Bezuspješno se pokušao sastati $s$ Tomom Didolićem, želeći razbistriti još neke stvari koje mu nisu bile jasne. ${ }^{181}$ Tomo Didolić ml. imao je svojih briga, jer je političkim porazom svojeg manevra trajno sveden na margine pokrajinske političke pozornice. Razmirice proizašle iz ovih izbora, prvenstveno oko izbora dr. Ivana Štambuka i odnosa selačke pravaške općine prema njemu, nastavljene su u novom obličju na općinskoj razini, ${ }^{182}$ što je tema koja zaslužuje zasebnu analizu.

\section{ZAKLJUČAK}

Iako je uoči devetih izbora za Dalmatinski sabor vladalo ozračje sloge Narodne hrvatske stranke i Stranke prava, ono je ipak splasnulo. Na izbore se izašlo tek djelomičnom suradnjom po izbornim kotarevima. Načelno su rezultati izbora

\footnotetext{
177 MHAS, D262, Pismo F. Radića L. Marunu 26. 11. 1901.

178 MHAS, D263, Pismo F. Radića L. Marunu 12. 12. 1901.

179 MHAS, D266, Pismo F. Radića L. Marunu 31. 12. 1901.

180 MHAS, D268, Pismo F. Radića L. Marunu 8. 1. 1902.

181 MHAS, D267, Pismo F. Radića L. Marunu 30. 1. 1902.

182 Mjestne razmirice, Narodni list, br. 27, 2. 4. 1902.
} 
otvorili perspektivu čvršćoj parlamentarnoj suradnji dviju stranaka uslijedbrojnih nadolazećih promjena na političkoj pozornici Dalmacije i Hrvatske. Usprkos tomu, u pojedinim kotarevima došlo je do žestoke borbe između narodnjaka i pravaša. Posebno su zapaženi bili polemički odjeci kontroverznog izbora u kotaru vanjskih općina Brača, Hvara i Visa. U ovom kotaru izborna borba nije bila uzrokovana suprotstavljenim programskim gledištima; o programima se nije ni govorilo, već su taktike i načela pojedinaca diktirali razvoj događaja. Parcijalni stranački interes narodnjaka za osvajanjem oba zastupnička mandata naišao je na odlučnu konfrontaciju pravaša. Ujedinjeni pravaši predvođeni Tomom Didolićem mlađim nastupili su protiv narodnjaka pozivajući se na odbijanje kompromisa u ovom kotaru od strane narodnjačke političke nomenklature. Budući da je ishod izbora ovisio o opredjeljenju bolskih i pučiških biranih birača, do zadnjeg trenutka svi su izborni ishodi bili mogući. Posebno je aktualna bila pravaška kandidatura učitelja Frane Radića. Na koncu je uz narodnjaka Jurja Carića iznenađujuće izabran Franin brat, bolski načelnik Ante Radić, dok je uz čistog pravaša don Ivu Bojanića neuspješno kandidaturu istaknuo bivši zastupnik Tomo Didolić ml. U polemikama koje su uslijedile rašomonski su se nizale različite perspektive iz kojih proizlazi sva složenost i slojevitost političke kombinatorike koja često ostavlja varljiv jednodimenzionalan dojam o izbornim procesima u dalmatinskom kurijalnom sustavu. Konzultiranjem arhivske građe iz pet arhivskih fondova može se rekonstruirati slijed događaja koji ukazuje da narodnjaci zaista nisu imali namjeru sporazumjeti se $s$ umjerenim pravašima $u$ ovom kotaru u kojem je pravaštvo bilo snažno politički prisutno. To je izazvalo konkretan odgovor druge strane u vidu suradnje s pristašama Prodanove Čiste stranke prava. $S$ obzirom na presudnu važnost glasova bolskih biranih birača kojima je upravljao načelnik Ante Radić, može se zaključiti kako je u kontekstu tijesnog omjera snaga između pravaša i narodnjaka Radić iskoristio taj politički kapital kako bi omogućio narodnjacima osvajanje oba mandata u ovom kotaru, od kojih je jedan priskrbio sebi. Zahvaljujući sačuvanoj korespondenciji fra Luje Maruna dobiva se uvid u razočaranje njegova brata, nesuđena kandidata Frane Radića, takvim ishodom. 


\section{IZVORI I LITERATURA}

\section{IZVORI:}

Hrvatska - Državni arhiv u Splitu, Split (HR-DAST), Obiteljski fond Duboković Nadalini (HR-DAST-617)

Hrvatska - Hrvatski državni arhiv, Zagreb (HR-HDA), Tresić Pavičić Ante (HRHDA-834)

Muzej hrvatskih arheoloških spomenika, Split (MHAS), Korespondencija Frano Radić - Lujo Marun (MHAS + D)

Nacionalna i sveučilišna knjižnica u Zagrebu, Zagreb (NSK), Ostavština Frane Radića (R 6300 C)

Sveučilišna knjižnica u Splitu, Split (SVKST), Arbiv dr. Ante Trumbića (SVKST, Arhiv Trumbić + M)

\section{TISKANI IZVORI:}

Brzopisna izvješća XXXI zasjedanja pokrajinskoga sabora dalmatinskoga od dneva 25. siječnja do dneva 10. veljače 1896., Zadar, 1896.

Brzopisna izvjeśća XXXVII zasjedanja pokrajinskoga sabora dalmatinskoga od dneva 24 juna do dneva 26 jula 1902, Zadar, 1902.

Kronika kapetana Nike Dubokovića, (ur. Pavao Palaversić), Jelsa, 1998.

Odgovori tiskani u Brojevim 6. i 8. "Jedinstva" godine 1902. na otvoreno pismo upravljeno od gospodina Tome Didolića, mlagjega gospodinu Antunu Radiću načelniku Bola i novoizabranom zastupniku naroda na Dalm. Saboru, Split, 1902.

$O$ osnovanju vinarske zadruge $A$. Radić pok. Gjura svojim sumjeśćanima u Bolu godine 1899., Split, 1899.

Otvoreno pismo gospodinu Anti Radiću načelniku u Bolu i novoizabranom zastupniku upravljeno od gospodina Tome Didolića, mladjega predstavnika obćine selačke i biranog birača, Zadar, 1902.

\section{NOVINE:}

Crvena Hrvatska, studeni 1901.

Hrvatska, prosinac 1901.

Hrvatska kruna, prosinac 1901. - siječanj 1902., veljača 1908.

Il Dalmata, veljača 1902.

Jedinstvo, listopad 1901. - ožujak 1902.

Katolička Dalmacija, lipanj 1889. 
Novi list, listopad - prosinac 1901., veljača 1902.

Obzor, prosinac 1901.

Narodni list, srpanj 1886., svibanj - lipanj 1889., kolovoz - listopad 1895., listopad 1901. - travanj 1902., ožujak 1912. (jubilarni broj)

\section{LITERATURA:}

Stjepan Ćosıć, Antun Stražičić i dubrovački Srbi katolici, u: Dubrovački koluri: uspon i pad srbokatolika, ur. Stjepan Ćosić, Dubrovnik, 2018., 5 - 30

Marjan Di Klić, Pravaštvo u Dalmaciji do kraja Prvoga svjetskog rata, Zadar, 1998. Katarina PAvešıć, Obiteljska sjećanja, u: Frano Radić: život i djelo, Zbornik radova, ur. Jakov Karmelić i Jadranka Nejašmić, Split, Bol, 2019., 15 - 17

Ivo PERIĆ, Dalmatinski sabor: 1861.-1912. (1918.) god., Zadar, 1978.

Ivo Perić, Politički skup hrvatske mladeži u Selcima (1883.) u svjetlu početnog širenja pravaštva na dalmatinskom prostoru, Radovi Zavoda za povijesne znanosti HAZU u Zadru, sv. 37, Zadar, 1995., 717 - 728

Ivan Kazimir Ostojıć, Tomo Didolić i njegovo dopisivanje, Split, 1929.

Marijo Ostojıć (Petrov), Pjesnici braća Ostojić, u: Povaljski zbornik, Zbornik radova, ur. Marijo Ostojić Petrov, Split, 2007., 253 - 273

Nikša STANČıć, Jelsa na otoku Hvaru u vrijeme hrvatskog narodnog preporoda - o jednom modelu oblikovanja mediteranskih gradića i tipu nacionalne ideologije na hrvatskoj obali Jadrana u 19. stoljeću, u: Jelsa u hrvatskom narodnom preporodu Dalmacije, Zbornik radova, ur. Pavao Palaversić, Jelsa, 1994., $13-36$

Cvjetko ŠKARPA, Dinko Politeo: studija, Zagreb, 1933.

Dario Št ur. Maja Štambuk, Zagreb, 2019., 33 - 301

Josip VRANDEČIĆ, Narodni preporod na otoku Braču, u: Brački zbornik, br. 22, Zbornik radova, ur. Ivo Šimunović, Split, 2007., 169 - 189

Dasen VRsalović, Povijest otoka Brača, Zagreb, 2003. 
Jure TRUTANIĆ

CONTROVERSY OVER THE ELECTION OF BRAČ CANDIDATES

FOR THE DALMATIAN PARLIAMENT IN THE DISTRICT OF THE OUTSIDE MUNICIPALITIES OF BRAČ, HVAR AND VIS IN 1901

\section{SUMMARY}

This paper deals with the Dalmatian Parliament elections held in 1901 and the political atmosphere in which they were held, dealing primarily with the controversies arising from the elections in the district of the outside municipalities of Brač, Hvar and Vis. Apart from the contribution to better understand the curial electoral system and the electoral process in general in the province of Dalmatia, this research contributes to the knowledge of bottomup policy-making, depicted in specific local circumstances in light of politicalideological stratification between populists and right-wingers and the growth of the Party-of -Right in the province. In the regular elections for the Dalmatian Parliament in the outside municipalities of Brač, Hvar and Vis held on December 10 1901, the members of the Popular Party Juraj Carić and Ante Radić were elected. The candidates of the Party-of-Right, Ivo Bojanić and Tomo Didolić Jr., failed, even though the Party-of-Right represented a significant political factor in the district. The unexpected but successfully declared candidacy of the mayor of Bol, Ante Radić, caused numerous controversies because his rightwing brother's, teacher Fran Radićs, landslide victory was certain until the very end. The attempt to become a member of the parliament of Tomo Didolić Jr. in cooperation with pure right-wingers was also controversial. These developments introduced a month-long war with open letters, brochures and letters, which the public followed with interest. Dalmatian and trans-Velebit newspapers and the preserved archival material scattered in various archival holdings can reconstruct the sequence of developments which indicates that the populists led by Niko Duboković in this district had no intention to agree with the right-wingers. As they were politically powerful in the area, this provoked a concrete response from the other side, which decided to cooperate with the pure right-wingers. Given the crucial importance of the ballots of Bol's elected candidates led by Mayor Ante Radić, we can conclude that in the context of a narrow margin between the rightists and the populists, he made good use of this political capital to enable the populists to get both mandates in this district, one of which was his.

Keywords: Dalmatian Parliament elections, Party-of-Right in Dalmatia, Brač, Hvar, Ante Radić, Niko Duboković, Tomo Didolić Jr., Frano Radić. 